Harmful Algae

January 2018, Volume 71 Pages 57-77

http://dx.doi.org/10.1016/i.hal.2017.12.003

http://archimer.ifremer.fr/doc/00416/52756/

(c) 2017 Elsevier B.V. All rights reserved.

\title{
Pentaplacodinium saltonense gen. et sp. nov. (Dinophyceae) and its relationship to the cyst-defined genus Operculodinium and yessotoxin-producing Protoceratium reticulatum
}

\author{
Mertens Kenneth ${ }^{1,{ }^{*}}$, Carbonell-Moore Maria Consuelo ${ }^{2}$, Pospelova Vera ${ }^{3}$, Head Martin J. ${ }^{4}$, \\ Highfield Andrea ${ }^{5}$, Schroeder Declan ${ }^{5,6}$, Gu Haifeng ${ }^{7}$, Andree Karl B. ${ }^{8}$, Fernandez Margarita ${ }^{8}$, \\ Yamaguchi Aika ${ }^{9}$, Takano Yoshihito ${ }^{10}$, Matsuoka Kazumi ${ }^{10}$, Nézan Elisabeth ${ }^{11}$, Bilien Gwenael ${ }^{11}$, \\ Okolodkov Yuri ${ }^{12}$, Koike Kazuhiko ${ }^{13}$, Hoppenrath Mona ${ }^{14}$, Pfaff Maya ${ }^{15}$, Pitcher Grant ${ }^{16}$, \\ Al-Muftah Abdulrahman ${ }^{17}$, Rochon André ${ }^{18}$, Lim Po Teen ${ }^{19}$, Leaw Chui Pin ${ }^{19}$, Lim Zhen Fei ${ }^{19}$, \\ Ellegaard Marianne ${ }^{20}$
}

${ }^{1}$ Research Unit for Palaeontology, Ghent University, Krijgslaan 281 s8, 9000 Ghent, Belgium

${ }^{2}$ Oregon State University, Department of Botany and Plant Pathology, College of Agricultural Sciences, 2082 Cordley Hall, Corvallis, OR 97331-2902, USA

${ }^{3}$ School of Earth and Ocean Sciences, University of Victoria, OEASB A405, P.O. Box 1700 Box 1700 STN CSC, Victoria, BC, V8W 2Y2, Canada

${ }^{4}$ Department of Earth Sciences, Brock University, 1812 Sir Isaac Brock Way, St. Catharines, Ontario, L2S 3A1, Canada

${ }^{5}$ The Marine Biological Association of the United Kingdom, Citadel Hill, Plymouth PL1 2PB, United

Kingdom

${ }^{6}$ School of Biological Sciences, University of Reading, Reading RG6 6AJ, United Kingdom

${ }^{7}$ Third Institute of Oceanography, SOA, Xiamen 361005, China

8 IRTA, Crta. Poble Nou, Km 5.5, 43540 Sant Carles de la Rápita, Spain

${ }^{9}$ Kobe University Research Center for Inland Seas, Kobe 657-8501, Japan

${ }^{10}$ Institute for East China Sea Research (ECSER), Nagasaki University, 1551-7, Taira-machi, Nagasaki, 851-2213, Japan

${ }^{11}$ Ifremer, LER BO, Station de Biologie Marine, Place de la Croix, BP40537, F-29185 Concarneau Cedex, France

${ }^{12}$ Universidad Veracruzana, Instituto de Ciencias Marinas y Pesquerías, Calle Hidalgo núm. 617, Colonia Río Jamapa, Boca del Río, 94290 Veracruz, Mexico

${ }^{13}$ Graduate School of Biosphere Science, Hiroshima University, Kagamiyama 1-4-4, Higashi-Hiroshima, Hiroshima 739-8528, Japan

${ }^{14}$ Senckenberg am Meer, Deutsches Zentrum für Marine Biodiversitätsforschung (DZMB), Südstrand 44, D-26382 Wilhelmshaven, Germany

${ }^{15}$ Marine Biology Research Center, Ma-RE Institute, Zoology Department, University of Cape Town, Rondebosch 7701, South Africa

${ }^{16}$ Marine and Coastal Management, Private Bag X2, Rogge Bay 8012, Cape Town, South Africa

${ }^{17}$ Department of Biological and Environmental Sciences, Qatar University, Doha, Qatar

${ }^{18}$ Institut des sciences de la mer de Rimouski (ISMER), Université du Québec à Rimouski, 310 allée des Ursulines, Rimouski, QC, G5L 3A1, Canada

${ }^{19}$ Institute of Ocean and Earth Sciences, University of Malaya, 16310 Bachok, Kelantan, Malaysia

${ }^{20}$ Department of Plant and Environmental Sciences, University of Copenhagen, Thorvaldsensvej 40,

DK-1871, Frederiksberg, Denmark 
*Corresponding author : Kenneth Neil Mertens, email address : kenneth.mertens29@gmail.com

\begin{abstract}
:
Strains of a dinoflagellate from the Salton Sea, previously identified as Protoceratium reticulatum and yessotoxin producing, have been reexamined morphologically and genetically and Pentaplacodinium saltonense $\mathrm{n}$. gen. et sp. is erected to accommodate this species. Pentaplacodinium saltonense differs from Protoceratium reticulatum (Claparède et Lachmann 1859) Bütschli 1885 in the number of precingular plates (five vs. six), cingular displacement (two widths vs. one), and distinct cyst morphology. Incubation experiments (excystment and encystment) show that the resting cyst of Pentaplacodinium saltonense is morphologically most similar to the cyst-defined species Operculodinium israelianum (Rossignol, 1962) Wall (1967) and O. psilatum Wall (1967). Collections of comparative material from around the globe (including Protoceratium reticulatum and the genus Ceratocorys) and single cell PCR were used to clarify molecular phylogenies. Variable regions in the LSU (three new sequences), SSU (12 new sequences) and intergenic ITS 1-2 (14 new sequences) were obtained. These show that Pentaplacodinium saltonense and Protoceratium reticulatum form two distinct clades. Pentaplacodinium saltonense forms a monophyletic clade with several unidentified strains from Malaysia. LSU and SSU rDNA sequences of three species of Ceratocorys ( $C$. armata, $C$. gourreti, $C$. horrida) from the Mediterranean and several other unidentified strains from Malaysia form a well-supported sister clade. The unique phylogenetic position of an unidentified strain from Hawaii is also documented and requires further examination. In addition, based on the V9 SSU topology (bootstrap values $>\mathbf{8 0 \%}$ ), specimens from Elands Bay (South Africa), originally described as Gonyaulax grindleyi by Reinecke (1967), cluster with Protoceratium reticulatum. The known range of Pentaplacodinium saltonense is tropical to subtropical, and its cyst is recorded as a fossil in upper Cenozoic sediments. Protoceratium reticulatum and Pentaplacodinium saltonense seem to inhabit different niches: motile stages of these dinoflagellates have not been found in the same plankton sample.
\end{abstract}

\title{
Highlights
}

Pentaplacodinium saltonense gen. et sp. n. is described from the Salton Sea. Cover plate, 5 precingulars, contact $1^{\prime}$ and Sa, shape, displacement are distinct. The genus is well-separated in LSU, SSU and ITS phylogenies. The chorate cysts of $P$. saltonense, correspond to Operculodinium psilatum. Distribution of Pentaplacodinium saltonense is considered subtropical to tropical.

Keywords: Pentaplacodinium, Protoceratium, Precingular plates, Salton Sea, Ceratocorys, Operculodinium, Cribroperidinioideae 


\section{Introduction}

The dinoflagellate genus Protoceratium was erected by Bergh (1881, p. 242) with Protoceratium aceros as the type species (fig. 36), which was recovered from Strib, Denmark. Bütschli (1885, p. 1007, plate 52, fig. 2) considered Peridinium reticulatum as described earlier by Claparède and Lachmann (1858) from Bergen Fjord, Norway, as a senior synonym, and he proposed the combination Protoceratium reticulatum. He also considered Clathrocysta reticulata as described by Stein (1883) a junior synonym. The plate formula for $P$. reticulatum, 4', 0a, 6", 6"', 1p, 1"'", was first provided by Wołoszyńska (1929) through the study of Baltic Sea specimens. Reinecke (1967) erected the name Gonyaulax grindleyi for specimens from Elands Bay in Cape Town, South Africa, with the tabulation 3', 1a, 6", 6"', $1 \mathrm{p}, 1^{\prime \prime \prime \prime}$. Based on a detailed study of the theca of Protoceratium reticulatum from the North Sea, Stosch (1969) considered G. grindleyi to be a junior synonym of $P$. reticulatum, although he considered it assignable to the genus Gonyaulax. Dodge (1989) agreed with the tabulation of Reinecke (19679), but retained the genus Protoceratium because he considered it different from his emendation of the genus Gonyaulax, by having only one intercalary plate. Hansen et al. (1997) restudied specimens close to the type locality of P. aceros, and based on the plate analysis concluded that $P$. reticulatum, $P$. aceros and $G$. grindleyi were conspecific, and agreed with the tabulation of Wołoszyńska (1929). Paez-Reyes and Head (2013) reviewed the morphological variability reported for P. reticulatum and concurred with Dodge (1989) in maintaining Protoceratium as a distinct genus from Gonyaulax.

149 Since the early 1900 's, s Seven other Protoceratium species have been described since the early 1900s, and the latest review of these taxa was-having been performed by Schiller (1937 p. 322-326). Kofoid (1907) described P. areolatum from the tropical Pacific and emended the genus for the first time. Meunier (1910) described a very similar species from 
the Kara Sea that he named Protoceratium splendens, which is possibly a junior synonym, as suggested by Gómez (2012). Later, Kofoid in Kofoid and Michener (1911) emended Protoceratium once more to include several new species from the eastern tropical Pacific that were described without illustration $(P$. cancellorum, $P$. globosum, $P$. pellucidum, $P$. pepo, $P$. promissum), and he suggested a tabulation formula for the genus: $2^{\prime}, 0 \mathrm{a}, 6^{\prime \prime}(? \mathrm{c}), 6^{\prime \prime \prime}, 0 \mathrm{p}, 3^{\prime \prime \prime \prime}$. Schiller (1937) transferred Clathrocysta aculeata as described by Stein (1883) to

Protoceratium aculeatum, presumably based on the fact that Bütschli (1885) had considered the genus Clathrocysta described by Stein 1883 as a junior synonym of Protoceratium. Schiller (1937) transferred Peridinium spinulosum as described by Murray and Whitting (1899) to the genus Protoceratium. Later, Balech (1988) rediscovered this species in the South-Wwest Atlantic and suggested yet another another variation on the tabulation for Protoceratium, 3', 0a, 6", 6"', 2"'", based on his observations of Protoceratium spinulosum. Protoceratium reticulatum (Claparède et Lachmann) Bütschli 1885 is a very common dinoflagellate found in cold and warm waters, as well as in oceanic and neritic environments (e.g., as Operculodinium centrocarpum in Zonneveld et al., 2013). - $\underline{\text { Its resting cyst distribution }}$ $\underline{\text { today reveals a strong link with the North Atlantic Current, an association traceable through }}$ the upper Cenozoic fossil record (Hennissen et al., 2017 and references therein). Protoceratium reticulatum is considered potentially toxic because of its production of yessotoxins (e.g. Paz et al., 2008; Sala-Pérez et al., 2016). It has been successfully isolated and cultured from many parts of the world, and grown into cultures. Cysts of P. reticulatum were first observed in cultures established from motile cells from the inner Oslofjord $t_{2}$ Norway) by Braarud (1945). This cyst was related by Wall and Dale $(1966,1967,1968)$ to the cyst-defined species described from the Miocene of Australia, Operculodinium centrocarpum (Deflandre et Cookson 1955) Wall 1967. That assignation was challenged by Head and Wrenn (1992) and Head (1996a) on the grounds that Operculodinium centrocarpum was 
larger and more robust than the cysts recorded by Wall and Dale (1966) from modern sediments. However, a $\underline{\mathrm{A}}$ restudy of the holotype of Operculodinium centrocarpum refuted this assignationconfirmed this, and the name "cyst of Protoceratium reticulatum" was recommended (Matsuoka et al., 1997). Wall and Dale (1968) proposed that P. reticulatum was also related to the cyst-defined Operculodinium psilatum Wall 1967 and furthermore possibly to Operculodinium israelianum (Rossignol 1962) Wall 1967. The cyst-defined Pyxidinopsis psilata (Wall et Dale in Wall et al., 1973) Head 1994 was subsequently also linked to Protoceratium reticulatum (Dale, 1996, as Tectatodinium psilatum) although this connection was later questioned tater(Mertens et al., 2011). Because of uncertainty regarding the links between the cysts produced by $P$. reticulatum (see Head, 2006), and eysts-cystdefined species named based onfrom the fossil records, $\underline{\text { Head (1996a, 1996b) and subsequent }}$ authors used the the term "Operculodinium centrocarpum sensu Wall and Dale, 1966" was used to describe the cysts that had first been observed by Braarud (1945) and Wall and Dale (1966). With the removal of Pyxidinopsis psilata as a potential cyst of Protoceratium reticulatum, Paez-Reyes and Head (2013) argued on the basis of non-overlapping geographic distribution that the "cyst of Protoceratium reticulatum" was now unambiguous and should replace the term "Operculodinium centrocarpum sensu Wall and Dale, 1966". That approach is followed here. Recent studies of variation in the process length of cysts of Protoceratium reticulatum have been related to variations in sea surface salinity and other parameters (e.g., Mertens et al. 2011; Jansson et al., 2014), and the cyst wall appears to be composed of cellulose glucan (Bogus et al. 2014). Resting cyst production through sexual reproduction has recently been demonstrated by Salgado et al. (2017).

Protoceratium reticulatum was assigned questionably to the subfamily Cribroperidinioideae by Fensome et al. (1993b) based on the presence of six precingular plates, L-type ventral organization and possible dextral torsion, which at the time had not 
been documented. This assignation was confirmed by Paez-Reyes and Head (2013). However, $€$ The description of the very-similar cyst-defined Operculodinium bahamense, with neutral torsion and modified L-type ventral organization, which would be placedallowing placement in the subfamily Leptodinioideae, either challenges-challenges such the present subfamilial classification of the Gonyaulacaceae, or implies that Operculodinium is polyphyletic, with both outcomes being possible -(Paez-Reyes and Head, 2013). Furthermore, molecular phylogenetics show that Protoceratium reticulatum is closely related to the family Ceratocoryaceae but not to the other extant cribroperidinean, Lingulodinium polyedra (Saldarriaga et al., 2004). It should also be noted that morphological variation and sequencing of cysts has suggested pseudocryptic speciation in $P$. reticulatum (Mertens et al., 2012a). Howard et al. (2009) investigated the phylogenetic relationships of yessotoxin-producing dinoflagellates, including several strains of $P$. reticulatum from different localities. Using Large Sub Unit (LSU) and Internal Transcribed Spacer (ITS) ribosomal DNA (rDNA) sequencing, they showed that the $P$. reticulatum strains formed a monophyletic clade in both phylogenies. However, $\Theta \underline{O}$ ne particular strain (CCMP404) isolated from the Salton Sea (California) in 1966 showed significant genetic differences from the other strains in both phylogenies. Despite these genetic differences, Howard et al. (2009) considered all the strains to belong to the species $P$. reticulatum.

The Salton Sea is the largest saline lake in California with a surface area of $980 \mathrm{~km}^{2}$ (Reifel et al., 2002). It has a mean depth of $8 \mathrm{~m}$ and a maximum depth of $15 \mathrm{~m}$ (Ferrari and Weghorst, 1997). Although originally composed of relatively freshwater, it has become saline due to a lack of outflow and high evaporation rates. During 1997-1999, the salinity was between 41 and $45 \mathrm{~g} \mathrm{l}^{-1}$ (Watts et al., 2001), while the temperature varied between about 12 and $40^{\circ} \mathrm{C}$ seasonally (Watts et al., 2001; Holdren and Montaño, 2002). Oxygen at times was supersaturated due to phytoplankton photosynthesis, but was also often severely depleted, 
occasionally even in surface waters (Watts et al., 2001; Holdren and Montaño, 2002). Reifel et al. (2002) reported P. reticulatum from the Salton Sea without illustration or description. In the present study, through reevaluation of the CCMP404 strain originated from the Salton Sea and observations of recently collected plankton samples from the Salton Sea, it iswe demonstrated that specimens living in the Salton Sea that have-had been-previously been identified as $P$. reticulatum, have a dissimilardifferent tabulation to that of $P$. reticulatum. To resolve this issue and accommodate these organisms, we have erected a new genus and new species, Pentaplacodinium saltonense $\mathrm{n}_{\text {. gen. }}$ et sp.is erected. From the-Salton Sea plankton samples, we describe the morphology of the thecate stage is described, showing significant differences with $P$. reticulatum. Similarly, through incubation of cysts from Salton Sea surface sediments ${ }_{2}$ we deseribe the corresponding cyst is described. Phylogenetic relationships are explored, including those with several unpublished sequences of $P$. reticulatum, Ceratocorys armata (Schütt 1895) Kofoid 1910, Ceratocorys gourretii Paulsen 1931, Ceratocorys horrida Stein 1883, and several unidentified strains. In addition, both the autecology and fossil record of Pentaplacodinium saltonense are examined.

\section{Material and Methods}

The cyst_-_theca relationship of $P$. saltonense was established through a germination experiment of a sample from the Salton Sea (CA, USA). To identify differences and similarities between $P$. reticulatum and $P$. saltonense, we compared the morphology of thecate stages of strains present in culture collections and other cells used for sequencing, arewere compared (Table 1, Suppl. Table 1). In addition, we studied the phylogenies arewere constructed ffusing LSU, ITS and SSU rDNA based sequences of $P$. saltonense and $P$. reticulatum from several of the same cells or cultured strains, as well as three Ceratocorys 
species isolated from the Mediterranean, and several unidentified strains from Hawaii and Malaysia (Table 1, Suppl. Table 1).

\subsection{Morphological study-imaging of cells in from plankton samples and strains present in} culture collections with microscopy

Plankton samples were obtained from the Salton Sea (California, U.S.A.; $33.50{ }^{\circ} \mathrm{N}, 115.91$ $\left.{ }^{\circ} \mathrm{W}\right)$ on 24 Oct. 2013 using a plankton net with a $20 \mu \mathrm{m}$ mesh size. These samples were fixed with ethanol (50\% final concentration) and stored cold. Several strains from previously sequenced strains from culture collections established from several other locations were also studied using transmitted light or scanning electron microscopy (Figure 1, Table 1). For scanning electron microscopy (SEM) of thecate stages by M.C.C--M., samples were prepared either by filtering a plankton sample or culture, or isolating a single cell under

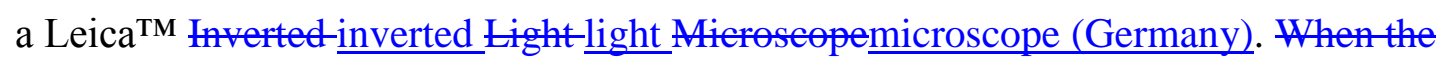
sSamples were was-filtered- by placing an aliquot of $~ 300 \mu \mathrm{L}$ aliquot was placed on a Millipore $^{\mathrm{TM}} 0.25 \mathrm{~mm}$ diameter-_5_- $\mu \mathrm{m}$ pore--polycarbonate filter at the bottom of a Millipore ${ }^{\mathrm{TM}}$ column. Approximately $7 \mathrm{~mL}$ of distilled water were added to remove the fixative (ethanol, lugol or formaldehyde) and seawater. A gentle manual vacuum with a $60 \mathrm{cc}$ syringe was used to speed filtration. Individually isolated ceCells were removed using a glass

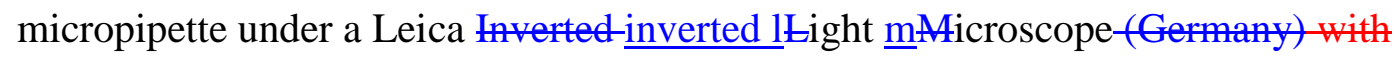
magnification $10 \times 5 \times$. Individual cells were washed six times with distilled water in double depression microscope slides). After the cells were clean, they were placed on the same kind of filter as for the filtered samples. All filters were air-dried, then adhered-affixed to $25 \mathrm{~mm}$ diameter aluminium stubs with adhesive tabs (7/16" diameter). The mounted filters were then coated with a mixture of gold-palladium in a Cressington Sputter Coater (U.S.A.) for $60 \mathrm{~s}$. 
Observations were performed with a FEI Quanta 3D Dual Beam SEM (Clackamas, Oregon,

279 U.S.A.), at $5 \mathrm{kV}$. Tilts up to $52^{\circ}$ were applied. Digital images were saved in Tiff format (2048

280 x 1768 pixels). Adobe-_Photoshop ${ }^{\mathrm{TM}}$ software was used to remove the background while maintaining the integrity of the original image.

For scanning electron microscopy_(SEM)_of culture CCMP 3243 by K.N.M., the culture was filtered and washed with distilled water and dehydrated in a graded ethanol series (30 to 100\% in six steps). The filters were encased in metallic baskets, critical-point dried with $\mathrm{CO}_{2}$ (CPD Bal-Tec 030), glued onto stubs, sputter coated with platinum/palladium for 90 s (JEOL JFC-2300 HR) and examined in a JEOL 6330F scanning electron microscope (JEOL, Tokyo, Japan) at the University of Copenhagen.

Measurements of thecate-thecae stages-of the newly described species were done conducted by M.C.C--M. under SEM. For each motile cell, the length was measured along the eenter of the-longitudinal axis, the width was measured along the middle of the cingulum, perpendicular to the longitudinal axisfrom one lateral margin to the other. All motile cell measurements in the species descriptions cite the minimum, average (in parentheses) and maximum values (in $\mu \mathrm{m}$ ), in that order. The standard deviation (SD) is also provided where appropriate.

Labelling of tabulation follows a modified Kofoid system that recognizes homologs (e.g., Fensome et al. 1993마). The sulcal plate labelling is-according tes with Balech (1980).

\subsection{Germination experiment of cysts of $\mathrm{P}$. saltonense}

Sediment samples were collected from the Salton Sea(CA, U.S.A.) aton the same timeday efas plankton sample collectionon, during the same field campaign_-on 24 October: 2013 , using a Petite Ponar Grab at shallow water depths $(<0.5 \mathrm{~m})$. All samples were stored in plastic 
bags in a refrigerator at $4^{\circ} \mathrm{C}$. In--situ sea surface salinities and sea surface temperatures were measured during sampling (Table 1).

About $0.5-1.0 \mathrm{~cm}^{3}$ of wet sediment was immersed in filtered seawater and, after one minute of ultrasonication using an ultrasonic bath, the sediment was rinsed through a $20 \mu \mathrm{m}$ nylon-_mesh sieve using filtered seawater. From this residue, the cyst fraction was separated using the heavy-liquid sodium polytungstate (SPT) at a density of $1.3 \mathrm{~g} \mathrm{~cm}^{-1}$ (Bolch, 1997). Single cysts were then transferred to Orange $\underline{S} s c i e n t i f i c ~ 0.5 \mathrm{~mL}$ microwells subjected to an irradiance of $100 \mu \mathrm{mol}$ photons $\mathrm{m}^{-2} \mathrm{~s}^{-1}$ and 24-hour light, and filled with $\mathrm{f} / 2$ medium at room temperature and a salinity of 35 psu. Cysts were regularly checked for germination, and observations were performed under a Leitz DM IL inverted light microscope. Encysted and excysted cysts, as well as motile cells, were photographed and measured using a Leica DM5000B light microscope with 100x oil immersion objectives.

\subsection{Morphological study of cysts extracted from surface sediments th using light} microscopy and SEM

Surface sediment samples were collected from several sites in the-Salton Sea sites were ebtained forto study of cysts of Pentaplacodinium saltonense (Table 1). Palynological techniques were used for processing (e.g., Pospelova et al., 2010; Mertens et al., 2012b). Material was rinsed twice with distilled water to remove salts. The samples were oven-dried at $40^{\circ} \mathrm{C}$ and then treated with room-temperature $10 \%$ hydrochloric acid $(\mathrm{HCl})$ at room temperature to remove calcium carbonate particles. To dissolve siliceous-silicate particles, samples were treated with $48-50 \%$ room-temperature-hydrofluoric acid (HF) at room temperature for two days, and then treated for $10 \mathrm{~min}$ with room-temperature $\mathrm{HCl}(10 \%)$ to remove fluorosilicates. The residue was rinsed twice with distilled water, ultrasonicated for 
$\sim 30 \mathrm{sec}$ and finally collected on a $15 \mu \mathrm{m}$ mesh. Aliquots of residue were mounted on microscope slides using glycerine jelly.

All measurements and light photomicrographs were obtained by K.N.M., and V.P., respectively using an Olympus BX51 with a Nikon digital sight DS-1L 1 module, and a Nikon Eclipse 80i transmitting light microscope with a DS-L2 module, all with 100x oil immersion objectives.

For each cyst, the lengths of the three longest visible processes with the corresponding widths at their base were measured within the focal plane. Process length was measured from the middle of the process base to the process tip. The average distance between processes was determined by measuring the distance between a process near the center of the cyston the upper surface of the cyst near the centreer and the five processes nearest to $i_{2}$ as measured between the middle of the process bases as seen from the surface of the cyst. The central body wall thickness was measured at two to three positions around the cross section of each cyst. The central body maximum and minimum diameters were also measured unless specimens were overly compressed or broken. Fragments representing less than half of a cyst, and cysts with mostly broken processes, were not measured. All cyst measurements in the species descriptions cite the minimum, average (in parentheses) and maximum values (in $\mu \mathrm{m}$ ), in that order. The standard deviation (SD) is also provided where appropriate.

For SEM observation of cysts at Geotop (the Université du Québec à Montréal, Canada), single specimens were picked under an inverted microscope with a micropipette, sputter coated with platinum/palladium for $60 \mathrm{~s}$ and observed using a scanning electron microscope (Hitachi S-3400N SEM). 
354 Isolated cells were washed three times in serial drops of $0.22 \mu \mathrm{m}$ filtered and sterilized

373 Isolated cells were washed three times in serial drops of $0.22 \mu \mathrm{m}$ filtered and sterilized 374 distilled water and then transferred to a $0.2 \mathrm{~mL}$ PCR tube. Cells were subjected to three 375 376 seawater by micropipette. Each cell was transferred to a $200 \mu \mathrm{m}$ PCR tube containing $10 \mu \mathrm{L}$ of Quick Extract FFPE DNA Extraction Solution (Epicentre, Madison, WI, USA) and incubated for $1 \mathrm{~h}$ at $56^{\circ} \mathrm{C}$, then for 2 min at $90^{\circ} \mathrm{C}$. The resulting extract was used as a DNA template for the initial PCR amplification. Sequences of SSU and partial LSU rDNA were determined from single cells of $P$. saltonense. The PCR was performed with EconoTaq $2 \mathrm{X}$ Master Mix (Lucigen, Middleton, WI, USA) following the manufacture's protocols. The external primers (SR1 and LSU R2) were used for the initial PCR. The first PCR product was used as a DNA template for the second PCR. The following combinations of primer pairs were used separately for the second PCR: SR1 and SR12, 25F1 and LSU R2. Using the second PCR products as the template DNA, the third PCR were-was performed by the following combinations of primer pairs: SR1b and SR3, SR1b and SR5TAK, SR4 and SR7TAK, SR6 and SR9p, SR8p and SR12, 25F1 and 25R1, D3A and LSU R2. The dDetails of the primers are described in Takano and Horiguchi (2004) and Yamaguchi et al. (2016). The PCR protocols and sequencing are described in Yamaguchi et al. (2016).

\subsection{Sequencing of single cells of Protoceratium reticulatum from Elands Bay (South Africa),} originally described as Gonyaulax grindleyi by Reinecke (1967)

\section{distilled water and then transferred to a 0.2 mL PCR tube. Cells were subjected to three} rounds of heating to $95^{\circ} \mathrm{C}$ for 5 minttes and cooling on ice for 5 minttes to induce cellular lysis. $5 \mu \mathrm{L}$ of the cell lysate was then used as a template for PCR using primers to amplify a $168 \mathrm{bp}$ region of the SSU, encompassing the V9 region, V9 For (5'- 
GTACACACCGCCCGTC-3') V9 Rev (5'- TGATCCTTCTGCAGGTTCACCTAC-3')

(Lane-et al., 1991; Medlin et al., 1988). PCR reactions were carried out in $25 \mu \mathrm{L}$ volumes containing $5 \mu \mathrm{L}$ DNA template, 10 pmol each primer, 1 x buffer, $1 \mathrm{mM} \mathrm{MgCl}_{2}, 0.0025 \mathrm{mM}$ dNTPs, 0.5 Unit Gotaq polymerase (Promega). PCR reactions proceeded with an initial denaturation at $95^{\circ} \mathrm{C}$ for 5 minutes, followed by 35 cycles of denaturation at $95^{\circ} \mathrm{C}$ for 30 seconds, annealing at $54^{\circ} \mathrm{C}$ for 20 seconds and extension at $72^{\circ} \mathrm{C}$ for 20 seconds and a final extension step of $72^{\circ} \mathrm{C}$ for 5 minutes. PCR products were sequenced directly in both directions using the respective primers (Source Bioscience).

\subsection{Sequencing of unidentified cultured strains}

For strains from Hawaii and Malaysia, single cells were isolated from plankton samples (Suppl. Table 1) and washed three times with sterilized bi-distillate water and were used as the template to amplify about 1,430 bp of the LSU rRNA gene (D1-D6 domains), using the primers D1R (forward, 5' -ACCCGCTGAATTTAAGCATA-3' ) (Scholin et al., 1994), 281483R (reverse, $5^{\prime}$-GCTACTACCACCAAGATCTGC-3' ) (Daugbjerg et al., 2000), 1740 bp of the SSU rRNA gene, using the primers SR1(forward, $5^{\prime}$ TACCTGGTTGATCCTGCCAG-3' ) and SR12b (reverse, $5^{\prime}$ CGGAAACCTTGTTACGACTTCTCC-3' ) (Takano \& Horiguchi, 2006), and 600 bp of the total ITS1-5.8S-ITS2, using the primers ITSA (forward, 5' -CCTCGTAAC

\section{AAGGHTCCGTAGGT-3' ), ITSB (reverse, 5' -CAGATGCTTAARTTCAGCRGG)}

(Adachi et al., 1996). A $50 \mu \mathrm{L}$ PCR cocktail containing $0.2 \mu \mathrm{M}$ forward and reverse primer, PCR buffer, $50 \mu \mathrm{M}$ dNTP, $1 \mathrm{U}$ of Taq DNA polymerase (Takara, Dalian, China) was subjected to 35 cycles using a Mastercycler PCR (Eppendorf, Hamburg, Germany). The PCR 
reaction procedure was 4 min at $94{ }^{\circ} \mathrm{C}$, followed by 25 cycles of 1 min at $94{ }^{\circ} \mathrm{C}, 2$ min at 45 ${ }^{\circ} \mathrm{C}, 3 \mathrm{~min}$ at $72{ }^{\circ} \mathrm{C}$, and final extension of $7 \mathrm{~min}$ at $72{ }^{\circ} \mathrm{C}$. PCR products were sequenced directly in both directions using the ABI Big-Dye dye-terminator technique (Applied Biosystems, Foster City, CA, USA), according to the manufacturer's recommendations. DNA extracts from strains collected in Spain (processed at IRTA) were prepared according to the protocol described in Andree et al. (2011). The extracted DNA was used in the amplification of ITS-1, 5.8S, ITS-2 sequences utilizing primers described in Andree et al. (2011), and a partial LSU sequence was amplified utilizing the primers described previously in Hansen et al. (2000). The amplification reactions were carried out in $25 \mu \mathrm{L}$ volume containing: $10 \mathrm{mM}$ Tris- $\mathrm{HC} 1 \mathrm{pH} 8.3$ (at $25^{\circ} \mathrm{C}$ ), $50 \mathrm{mM} \mathrm{KCl,} 2 \mathrm{mM} \mathrm{MgC1}_{2}, 0.001 \% \mathrm{w} / \mathrm{v}$ gelatin, 400 pM dNTP's, $1 \mu \mathrm{M}$ of each primer, and $1 \mathrm{U}$ Taq polymerase. Amplifications were performed using the following parameters: $94^{\circ} \mathrm{C}$ for 5 min followed by 35 cycles of $95^{\circ} \mathrm{C}$ for $30 \mathrm{~s}, 50{ }^{\circ} \mathrm{C}$ for $45 \mathrm{~s}, 72{ }^{\circ} \mathrm{C}$ for $1 \mathrm{~min}$, and a final extension of $72{ }^{\circ} \mathrm{C}$ for $5 \mathrm{~min}$. The PCR products were purified using Qiagen spin columns (Qiagen PCR Purification Kit) and sent for bi-directional sequencing by a commercial company (Sistemas Genomicos, Valencia, Spain) utilizing the same primers as those used in the original amplification. The resulting nucleic acid sequence data was manually proofed using BioEdit (Hall et al., 1999) to confirm the consensus sequence.

The strain 091223-38_M16 from Helgoland (North Sea) was sequenced by M.H.. The Epicentre MasterPure complete DNA \& RNA Purification Kit was used for the DNA extraction. We use-puReTaq ready-to-go PCR beats arewere used; annealing temperature was $50^{\circ} \mathrm{C}$; 33 cycles; primers: ITS 1 (forward) 5' GGTGAACCTGAGGAAGGAT 3'; ITS4 (reverse) 5' TCCTCCGCTTATTGATATGC 3'. The PCR product of the right $\underline{\text { correct size }}$ was gel isolated (QIAquick Gel Extraction Kit). Sequencing was done by Macrogen with the ITS1 primer. 
Koike, were sequenced using methods mentioned in Mertens et al. (2012a). and 0976) acquired from the NCMA (National Centre for Marine Algae) using the DNeasy DNA extraction kit (Qiagen) according to manufacturers' instructions. The $760 \mathrm{bp}$ region of the LSU rRNA gene was amplified using $2 \mu \mathrm{L}$ DNA in PCR reactions spanning the D1-D2 variable region D1R (forward, 5'-ACCCGCTGAATTTAAGCATA-3'), D2C (reverse, 5'GCTTGGTCCGTGTTTCAAGA-3') (Scholin et al., 1994) a 168 bp region of the SSU rRNA gene (V9) V9 For (5'-GTACACACCGCCCGTC-3') V9 Rev (5'bp intergenic region ITS1, 5.8S, ITS2, EITS2 For (5'-GTAGGTGAACCTGCVGAAGA-3') EITS2 Rev (5'-TGGGGATCCTGTTTAGTTTC-3') (Guillou et al. 2002). PCR for V9 is detailed in section 2.5. For LSU and ITS, PCR reactions were carried out in $50 \mu \mathrm{L}$ volumes containing $2 \mu \mathrm{L}$ DNA, 20 pmol each primer, 1 x buffer, $1.5 \mathrm{mM} \mathrm{MgCl}_{2}, 0.0025 \mathrm{mM}$ dNTPs, 1 Unit Gotaq polymerase (Promega). PCR reactions proceeded with an initial denaturation at $95^{\circ} \mathrm{C}$ for 5 minutes, followed by 35 cycles of denaturation at $95^{\circ} \mathrm{C}$ for 30 secends, annealing at $60^{\circ} \mathrm{C}$ for 45 seconds and extension at $72^{\circ} \mathrm{C}$ for $1 \mathrm{~min}$ and a final extension step of $72^{\circ} \mathrm{C}$ for 5 minutes. PCR products were sequenced directly in both directions using the respective primers (Source Bioscience) and sequences were manually verified using Chromas XXXXXMG646283-MG646333. (Technelysium Pty Ltd) prior to phylogenetic analysis.

Novel sequences were deposited in Genbank under accession numbers 
Multiple sequence alignments were constructed for sequences generated for the variable regions V9 (SSU), D1-D2 (LSU) and partial ITS1, 5.8S, ITS2 (intergenic region), respectively, in BioEdit 7.0 (Hall 1999) using ClustalW along with other available sequences from Genbank. Alignments were trimmed accordingly based on the lengths of the sequences acquired and to allow for a sufficient number of sequences to be included in the phylogeny. Phylogenetic analysis based on neighbour-joining and maximum likelihood was undertaken using MEGA 6 (Tamura et al., 2013) using the default parameters. Bootstrap values were retrieved from 1000 replicates and are indicated on the nodes of the trees.

\section{Results}

\subsection{Study of plankton samples, culture strains, germination experiments, and surface sediments}

Investigation of plankton samples from the Salton Sea revealed the presence of a species that is superficially similar to P. reticulatum and is here assigned to Pentaplacodinium saltonense gen. et sp. nov.n. sp. Three process-bearing cysts (Plate 1) were isolated from surface sediments of the Salton Sea,California, USA (Table 1) and identical morphologies emerged from these cysts (Plate 2). These cells started dividing after germination, and one strain was maintained. The cells were identical in morphology to specimens observed in plankton samples from the Salton Sea (Plate 3), as well as to specimens from several culture strains (Plate 4, Suppl. Table 1), as described below.

\subsection{Systematics}


Division DINOFLAGELLATA (Bütschli 1885) Fensome et al. 1993므

Class DINOPHYCEAE Pascher 1914

Subclass PERIDINIPHYCIDAE Fensome et al. 1993므

Order GONYAULACALES Taylor 1980

Suborder Gonyaulacineae autonym

Family uncertain

Genus Pentaplacodinium Mertens, Carbonell-Moore, Pospelova et Head gen. n. (Plate 3) Type: Plate 3A, the holotype of Pentaplacodinium saltonense gen. et sp. nov.

Diagnosis: A genyaulacoid gonyaulacinean genus with roundish to slightly-polyhedral thecae with bearing heavily reticulated plates without appendicesappendages. The tabulation is Po,

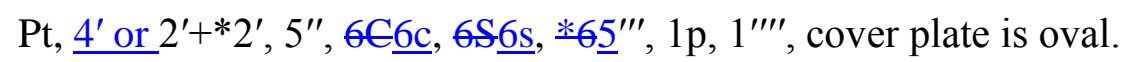

Etymology: The name is derived from the Greek words penta meaning five, plax plate, and dino whirling; with reference to the five precingular plates that characterize this dinoflagellate genus.

Pentaplacodinium saltonense Mertens, Carbonell-Moore, Pospelova et Head gen. et sp. n. (Plates 3, 4, Figs 2A, 3, 4A)

Synonymy:

1970 Protoceratium reticulatum (Claparède et Lachmann); Steidinger and Williams, p. 62, plate 38 , fig. $140 \mathrm{a}-\mathrm{c}$.

1991 Protoceratium reticulatum (Claparède et Lachmann); Al-Muftah, pp. 180-181, figs. $246-247$.

? 2002 Protoceratium reticulatum (Claparède et Lachmann); Reifel et al., p. 275.

2005 Gonyaulax grindleyi Reinecke; Faust et al., p. 110, figs. 2-4.

? 2007 Gonyaulax grindleyi Reinecke; Tiffany et al., p. 582. 

? 2009 “-Protoceratium globosum”-" Kofoid etand Michener; Morquecho et al., p. 18,_20, figs. $13-17$.

Diagnosis: Theca roundish to somewhat polyhedral with tabulation $\mathrm{Po}, \mathrm{Pt}, 2^{\prime}+* 2^{\prime}, 3 \underline{5}^{\prime \prime}+2^{\prime \prime}$,

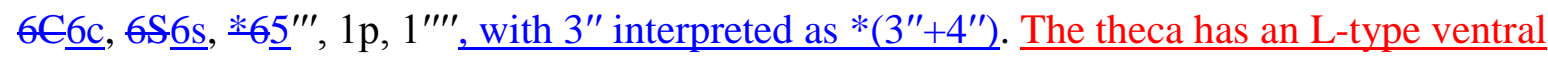
organization and dextral torsion. The plates are heavily reticulated with one pore inside each reticulation, although two or more pores might be found in reticulations next to a suture. The ends of the descending cingulum are displaced by $\sim 2.0$ widths. The cysts have an approximately roundish-spherical central body with a thin pedium and thicker spongy-fibrous luxuria. Processes-Process distribution apparently have a nointrantabular-distribution, ._are Processes fibrous and distally tapering, and have acuminate to minutely expanded distal ends. The archeopyle corresponds to the third $*^{*}\left(3^{\prime \prime}+4^{\prime \prime}\right)$ precingular plate and has a smooth margin with rounded angles. The operculum is free. Etymology: The specific epithet refers to the type locality for this species. Type locality: The Salton Sea, California, U.S.A. (station 1 at $33^{\circ} 30.192_{-}^{\prime \prime}$ N, $115^{\circ} 54.869_{-}^{\prime \prime}$ W). Gene sequence: The $28 \mathrm{~S}$ and $18 \mathrm{~S}$ gene sequence of the cell isolated from culture $2 \mathrm{E} 3$, established from a cyst extracted from surface sediment from station 2 in the Salton Sea (Table 1). - GenBank Accession No. XXXXXX-MG646301 (18S) and XXXXXX

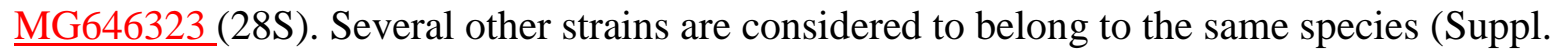
Table 1).

Holotype: Hllustrated on-Plate 3A. The specimen illustrated is on an SEM stub (designated CEDiT2017H62) will be deposited curated at the Senckenberg Research Institute and Natural History Museum, Centre of Excellence for Dinophyte Taxonomy, Germany. Description: Motile cells observed in the Salton Sea plankton samples (Plate 3, except D). The cell-shape varies fromThecae have a roundish to somewhat polyhedral shape (Plate 3A, C). The thecae have and a typical sexiform gonyaulacoid tabulation (sensu Fensome et al., 
1993므, tText-Fig. 64B) with an L-type ventral organization (sensu Fensome et al., 1993 $\underline{b}$, Text-Figs. 82A, C) and dextral torsion (sensu Fensome et al., 1993므, Text-Fig. 83C). The epitheca as often somewhat shorter in length than the hypotheca. The plates are reticulated with one pore inside each reticulation, although two or more pores eould-may occurbe found in reticulations next to a suture. All pores each contain $\sim 3$ minute pores (small arrowhead in Plate 3B). The reticulations are faintly expressed on the sulcus and cingulum (Plate 3C). The cell content is brownish-red owing to the presence of chloroplasts (Plate 2A). Several red bodies are present (Plate $2 \mathrm{~A}-\mathrm{C}$ ).

The apical pore complex consists of a cover plate surrounded by a pore plate (Plate 7F, $\mathrm{H})$. The oval cover plate, which is often absent (Plate 3B), is relatively broad and is surrounded by the pore plate. The pore plate is perforated by 5-7 large pores. A low apical collar may encompass the pore plate and is formed by the raised edges of the first and second apical plates, and the fourth apical homolog as well (Plate 3F, H). The first and second apical plates $\left(1^{\prime}\right.$ and $\left.2^{\prime}\right)$ and the fourth apical homolog $\left(* 4^{\prime}\right)$ are elongated. The first apical plate $\left(1^{\prime}\right)$ is rectangular, while-whereas the second apical plate $\left(2^{\prime}\right)$ and the fourth apical homolog $\left(*^{\prime}\right)$ are six-sided and irregularly shaped (Plate 3B). The third apical homolog $\left(*^{*} 3^{\prime}\right)$ is small and contacts $2^{\prime}$ and ${ }^{*} 4^{\prime}$, but in the specimens that were-observed it never contacted the apical pore plates (Plate 3B). There is a large ventral pore located posteriorly between 1 ' and *4' (Plates $3 \mathrm{~A}, \mathrm{~B}, 4 \mathrm{~A}-\mathrm{C})$. The precingular series consists of five large plates, where 2 " is the largest, $*\left(3^{\prime \prime}+4^{\prime \prime}\right)$ forms the keystone plate, and $* 6^{\prime \prime}$ is the smallest. Plates $1 ", *\left(3^{\prime \prime}+4{ }^{\prime \prime}\right)$, and $* 5^{\prime \prime}$ are five-sided, $2 "$ is four-sided, while * $6 "$ is six-sided (the suture with the anterior right sulcal is very small (Fig. 3) (Plates 3B, 4A-C). External views of the theca ean-could suggest that there would be no contact between the anterior sulcal plate and 1' (e.g., Plate 3A, B). However, pProperly oriented external views and internal views, however, show however $\mathrm{a}$ narrow contact between both plates (Plate 3D). This contact between the anterior sulcal plate 
and $1^{\prime}$, in combination with the contact between $* 6^{\prime \prime}$ and $1^{\prime}$ therefore results in an insert configuration (sensu Fensome et al. 1993므, Text-Fig. 62A). The cingulum is left-handed (descending), lined with narrow lists, and comprises six cingular plates. The ends of the cingulum do not overhang, and are displaced by $\sim 2.0$ widths (Plates $3 \mathrm{~A}, 4 \mathrm{~B}$ ).

The sulcus is narrow anteriorly and slightly widens posteriorly. It consists of six plates (Plate 3D, Fig. 3) - - the first postcingular plate 1"' is treated as a sulcal and labeled the anterior left sulcal plate (Ssa). The anterior sulcal plate $\underline{(\mathrm{Sa})}$ is relatively large and anteriorly intruded between plates $1^{\prime \prime}$ and $* 6^{\prime \prime}$ and barely contacts $1^{\prime}$ (Plate 3D). The anterior left sulcal plate (Ssa) is similar in size to the anterior right sulcal plate (Sda). Immediately below these two plates, lay the small posterior right sulcal (Sdp) and a much larger plate, the left posterior sulcal. Finally, there occurs the large posterior sulcal (Sp) is found, which presents lines of pores around its sutures with the adjacent non-sulcal plates (Plate 3D, Fig. 3).

The hypotheca is asymmetrical as a consequence of dextral torsion (Plates 3A). There are five homolog postcingular plates. Plate $* 2$ "' is irregularly shaped and the smallest in the series. All other postcingular plates are large, though $* 6^{\prime \prime \prime}$ is relatively smaller; in addition, they are trapezoidal and four-sided (Plates 3E, 4E). The posterior intercalary plate (1p) bears a conspicuous flange on its right margin (Plates 3A, 4C). The plate overlap is typical for gonyaulacoids, with $3^{\prime \prime}$ (in our case $*\left(3^{\prime \prime}+4^{\prime \prime}\right)$ ) forming the keystone plate (the plate that overlaps all adjacent plates) oin the epitheca, and ${ }_{-} 4$ "' forming the keystone plate oin the hypotheca (Fig. 4, Plate 3E).

Cysts from the Salton Sea surface sediments (Plates 1, 5). The central body is approximately sphericalroundish. The wall is thick, consisting of a thin, solid pedium that has a smooth inner surface, and a thicker spongy-fibrous luxuria that appears loosely granular in surface view. Processes are numerous and are solid and fibrous along their entire length, often loosely 
fibrous at the base. Process bases are expanded, and larger processes may be concave in

577 lateral profile for at least half of their length. Some closely adjacent processes are joined at the base. Most processes usually have a minute distal expansion, observed under SEM as a concave platform $\sim 1.0 \mu \mathrm{m}$ or less in diameter with strongly irregular margins that may be approximately perpendicular to the shaft. Alongside these, some processes on most specimens taper to distal points, and such processes occasionally predominate on eyst specimensindividual specimens. Processes are mostly of even height, but shorter and thinner processes may be interspersed. The process length/central body ratio is about 0.06 . Processes are not evenly spaced, and their parallel alignment and bands devoid of processes observed in many specimens suggest intratabular distribution. However, $\underline{\text { There is however no clear }}$ evidence of tabulation except for the archeopyle and often parallel alignment along the eingulumcingular margins. The archeopyle is formed from the loss of plate $*\left(3^{\prime \prime}+4^{\prime \prime}\right)$, is reduced, and has slightly rounded angles and straight margins. The-usuat archeopyle that is moderately wide and reflects the precingular thecal plate $*\left(3^{\prime \prime}+4^{\prime \prime}\right)$, whereas the operculum is released as a single piece, and has well defined to moderately rounded angles and straight $\underline{\text { margins, as illustrated on Plate } 1 \mathrm{G}-\mathrm{H} \text {. - A reentrant angle along the anterior margin of the }}$ archeopyle, signaling the fusion of plates $3^{\prime \prime}$ and 4", was not seen in the thecal or cyst tabulation of $P$. saltonense although this might not in fact be expected (see Below, 1987, p. 36, fig. 18a; translated in Fensome et al., 1993a, p. 844). An unusually wide archeopyle that seems to reflect two adjacent precingular thecal plates, $*\left(3^{\prime \prime}+4^{\prime \prime}\right)$ and $2^{\prime \prime}$, where the operculum is again released as a single piece, is illustrated on Plate 1C-E. If this interpretation is correct, then the component representing $2 "$ in the archeopyle/operculum is reduced in size, because on the theca the second precingular plate is actually similar or larger in size than the $*\left(3^{\prime \prime}+4^{\prime \prime}\right)$ plate. 
Dimensions: The holotype cell illustrated in Plate 3A, the holotype figure, is $44 \mu \mathrm{m}$ in length, $41 \mu \mathrm{m}$ in width and $38 \mu \mathrm{m}$ in depth. Germinated motile cells: length, 48.1 (53.7) $63.4 \mu \mathrm{m}$ $(\mathrm{SD}=6.0, \mathrm{n}=5)$; width, 38.5 (42.4) $47.5 \mu \mathrm{m}(\mathrm{SD}=3.2, \mathrm{n}=5)$. Cells observed in plankton from St. 2 in the Salton Sea: length, 37.8 (46.1) $59.8 \mu \mathrm{m}(\mathrm{SD}=5.5, \mathrm{n}=28)$; width, 31.0 (39.5) 48.5 $\mu \mathrm{m}(\mathrm{SD}=4.2, \mathrm{n}=28)$.

Two single cysts germinated to give the identifiable thecae: maximum central body diameter, $52.3(53.5) 54.7 \mu \mathrm{m}(\mathrm{SD}=1.7, \mathrm{n}=2)$; minimum central body diameter, 51.1 (52.2) $53.3 \mu \mathrm{m}$ $(\mathrm{SD}=1.6, \mathrm{n}=2)$; average length of three randomly chosen processes per cyst, 2.4 (3.0) $3.6 \mu \mathrm{m}$ $(\mathrm{SD}=0.4, \mathrm{n}=6)$; process width at base $1.4(2.2) 2.7(\mathrm{SD}=0.6, \mathrm{n}=6)$ and wall thickness $1.3(1.7)$ $2.1(\mathrm{SD}=0.3, \mathrm{n}=6)$. Palynologically treated cysts from surface sediments of the Salton Sea: maximum central body diameter, 48.6 (56.3) $70.9 \mu \mathrm{m}(\mathrm{SD}=5.3, \mathrm{n}=23)$; minimum central body diameter, 45.7 (52.1) $61.4 \mu \mathrm{m}(\mathrm{SD}=3.8, \mathrm{n}=22)$; average length of three processes per cyst, 1.0 (3.1) $5.7 \mu \mathrm{m}(\mathrm{SD}=1.2, \mathrm{n}=66)$; process width at base 1.0 (2.2) $3.9(\mathrm{SD}=0.6, \mathrm{n}=66)$ and wall thickness $0.9(1.6) 2.4(\mathrm{SD}=0.4, \mathrm{n}=66)$.

Comments: Pentaplacodinium saltonense $\mathrm{n}$. gen et sp. is defined primarily from the characters of the motile stage, these distinguishing it from species of the genus Protoceratium. The morphology of several thecae observed from off Yucatan (Gulf of Mexico), the Indian River Lagoon (Florida, USA), and off Qatar (Persian Gulf) (Table 1; Plate 2) and from cultures established from cells from Biscayne Bay (Florida, USA) (CCMP1720, CCPM1721), the Indian River Lagoon (Florida, USA) (CCMP3241, CCMP3243) and the Salton Sea (California, USA) (CCMP404) (Suppl. Table 13, Plate 1) agree with the description of $P$. saltonense given above. Cysts formed from cultures established from a strain from the Indian River Lagoon (Florida, USA) (CCMP3243) have the same morphologies (Plate 6). The observed cysts correspond most closely to the fossil based axon-species Operculodinium israelianum (Rossignol 1962) Wall 1967 described from the Pleistocene of Israel, and 
Operculodinium psilatum Wall 1967 described from the postglacial (Holocene) of the Caribbean, p. 111 112, Plate 6, figs. 6 8. However, Operculodinium israelianum has longer processes (6-10 $\mu \mathrm{m}$; Rossignol, 1964), and $O$. psilatum has a psilate surface interrupted by $\underline{\text { minute and sparsely distributed processes, and a pronounced cingulum (Wall, 1967). Both }}$ have archeopyles that are less wide than for the cyst of $P$. saltonense.

\subsection{Phylogenetic position of $\mathrm{P}$. saltonense and other studied strains}

The SSU rDNA sequences for all $P$. reticulatum strains analysed were identical, forming a distinct clade separated from the $P$. saltonense sequences which were identical to the unidentified Malaysian sequences (Fig. 5). P. reticulatum and $P$. saltonense sequences shared $92 \%$ nucleotide identity for the V9 region analysed.

For the LSU rDNA V4 analysis (Figure 6), P. reticulatum sequences were identical apart from a couple of sporadic nucleotide substitutions which were ealled $\underline{\text { identified as }}$ ambiguous bases by the sequencing software. The unidentified strain from Hawaii had 12 nucleotide substitutions across the 570_bp multiple sequence alignment compared to $P$. reticulatum. $P$. saltonense sequences shared more similarity with the unidentified $\mathrm{GgSm}$ strains from Malaysia (96\%) compared to that of P. reticulatum (94\%).

The ITS (intergenic region between ITS1 and 2) was the only marker to resolve intraspecific diversity within the $P$. reticulatum species, with strain E12 (Baffin Bay, Arctic) sharing 98\% nucleotide similarity with strain VG0757 isolated from Spain. The phylogeny separates $P$. reticulatum into two large subclades: subclade 1 A that regroups several strains from warmer waters, and subclade 1B that regroups several strains from colder waters (Fig 7).

49 The three phylogenies (Figures- 5-7) show that strains identified as Protoceratium reticulatum form a monophyletic group (Clade 1), as well as strains identified as $P$. 
saltonense that form a clade with the unidentified GgSm strains from Malaysia (Clade 2), as well as the Ceratocorys species that form a clade with PrTT strains from Malaysia (Clade 3) supported by high bootstrap values (>70). The unidentified strain from Hawaii does not group with the Protoceratium reticulatum or Pentaplacodinium saltonense clades. The topology of the trees are-is not consistent between the three phylogenies (i.e. the relatedness between clades), however but the three clades identified are consistently formed. The trees furthermore highlight the unexplored diversity within this group of dinoflagellates, and further incubation and plankton studies from these locations should reveal whether the unidentified strains are new species or not.

In addition, the phylogenies show that V9 SSU sequences from cells from Elands Bay (South Africa), (bootstrap values $>80 \%$ ), that have been previously identified as G. grindleyi by Reinecke (1967), clusters with Protoceratium reticulatum (Fig-ure 5).

The three studied species of Ceratocorys (C. armata, $C$. gourreti, $C$. horrida) share high nucleotide similarity for the SSU (100\%) and LSU sequences (>99\% identity) (Figure 6).

\section{Discussion}

\subsection{Comparison of the eell theca of $\mathrm{P}$. saltonense}

Pentaplacodinium saltonense differs from Protoceratium reticulatum because it bears five precingular plates, whereas $P$. reticulatum has six precingular plates. Furthermore, $P$. saltonense has a larger eingulum-cingular displacement (2 widths vs. 1 width respectively) and an oval cover plate, as opposed to a sigmoidal cover plate in P. reticulatum. In addition, the theca of $P$. saltonense is mostly roundish, whereas in $P$. reticulatum it is always polyhedral. Both species have an insert configuration, but in $P$. saltonense the contact 
between Sa and 1' is very narrow whilst whereas in $P$. reticulatum this contact is wide - this causes an evident conspicuous separation between $1 "$ and $6 "$ in $P$. reticulatum, when in $P$. saltonense there is an apparentalmost a small point of contact between those two plates (Plate 1D每). Gonyaulax grindleyi Reinecke 1967 is here considered shown to be a synonym of $P$. reticulatum, as it has been-already suggested by von Stosch (1969) and Hansen et al. (1997), and is now confirmed by the LSU rDNA phylogeny in this study (see below).

Several other Protoceratium species have been described (e.g. Schiller, 1937, p. 322326). Protoceratium splendens Meunier 1910 from the Kara Sea has six precingular plates; it is possibly a junior synonym of Protoceratium reticulatum, as suggested by Gómez (2012). Protoceratium aculeatum (Stein 1883) Schiller 1937 bears antapical spines and an apical horn. Protoceratium areolatum Kofoid 1907 and Protoceratium spinulosum (Murray and Whitting 1899) Schiller 1937 have fewer reticulations in both the epitheca and hypotheca than P. saltonense. Of the five species described by Kofoid and Michener (1911):-2, Protoceratium cancellorum, Protoceratium pellucidissimum, Protoceratium pepo, Protoceratium globosum and Protoceratium promissum, none have has illustrations and it is therefore it is-impossible to compare them to $P$. saltonense.

Pentaplacodinium saltonense differs from Ceratocorys anacantha Carbonell-Moore 1996 because it is not as polyhedral. In addition, in contrast to the insert epithecal configuration of $P$. saltonense, $C$. anacantha has an episert type I epithecal configuration, meaning that $1^{\prime}$ does not contact the anterior sulcal plate and that $1^{\prime \prime}$ and $6^{\prime \prime}$ are in contact (Paez-Reyes and Head, 2013).

\subsection{Comparison of the cyst of $\mathrm{P}$. saltonense}


The cyst of Pentaplacodinium saltonense cerrespends toompares with Operculodinium psilatum because its cysts display an alignment of processes along the cingulum, it bears short

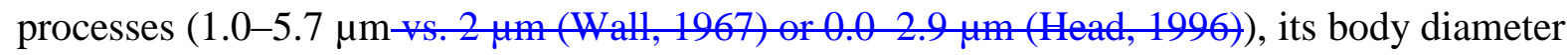
is of similar size (45.7-70.9 $\mu \mathrm{m}$ vs. $50-60 \mu \mathrm{m}+_{2}$ Wall, 1967); or 62-79 $\left.\left.\mu \mathrm{m}-_{2} \mathrm{Head}, 1996 \underline{\mathrm{b}}\right)\right)$

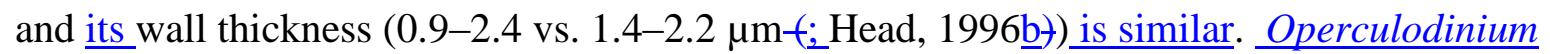
psilatum differs, however, in having processes that in general are shorter $(2 \mu \mathrm{m}$, Wall, 1967; $\underline{0.0-2.9 \mu \mathrm{m}, \text { Head, 1996b) and sparsely distributed. The cingulum and sulcus are also more }}$ conspicuously expressed in Operculodinium psilatum (Wall, 1967; Head et al., 1996b), and $O$. psilatum lacks the wide archeopyle of $P$. saltonense.

The cyst of $P$. saltonense is also similar to Operculodinium israelianum (Rossignol 1962) Wall 1967 as described by Rossignol (1964, as Baltisphaeridium israelianum); however, although the processes of the latter species are longer $(6-10 \mu \mathrm{m})$ than ef the specimens from Salton Seafor $P$. saltonense $(1.0-5.7 \mu \mathrm{m})$. At this time, we do notilt is not presently known whether variation in process length is related to variations in ecology, similar teas demonstrated for the cysts of Lingulodinium polyedra (=Lingulodinium machaerophorum) (Mertens et al., 2009), cysts of Protoceratium reticulatum (Mertens et al., 2011) and cysts of Pyrodinium bahamense (=Polysphaeridium zoharyi) (Mertens et al., 2015). In addition, $t \underline{T h e}$ process distribution appears to be is-intratabular for the cysts of $P$. saltonenseand often shows parallel alignments, which is not readily visibleand this is likely to be the case also for-on_O. israelianum (e.g., O. cf. israelianum of Head, 1997, fig. 17.2), although the study of topotype material will be needed for confirmation. The rounded angles of the archeopyle in O. israelianum, O. psilatum and the cysts of Pentaplacodinium saltonense, and the shared presence of a spongy-fibrous to fibroreticulate luxuria, accentuate the overall similarities between these cysts, although the relatively wider archeopyle in $P$. saltonense cysts distinguishes them from these other species. 
We tTherefore, it is not considered it not to be a morphological variant of

Operculodinium israelianum. There is reasonable doubt that Operculodinium israelianum is

727

728 related to another species: Wall and Dale (1968) (and subsequently Dale, 1983) have suggested that $\theta$. israelianum can be related to Protoceratium reticulatum. Operculodinium israelianum is very similar toresembles the Miocene Operculodinium centrocarpum (Deflandre et Cookson 1955) Wall 1967, which is-also has a spongy-fibrous luxuria, although it is somewhat larger $(54-80 \mu \mathrm{m})($; Deflandre and Cookson, 1955) and has longer processes. $\underline{\text { Head (1996b) noted an intergradation in size and process length between } O \text {. israelianum and }}$ O. centrocarpum in Pleistocene assemblages of eastern England. It is of interest to remark that specimens from the Ludham borehole intergrade between $\theta$. isfaelianum and $\theta$. centrocarpum Deflandre et Cookson 1955 (Head, 1996).A restudy of both holotypestopotype material as well as theis needed to confirm the range of variability within each species-would be needed to resolve this issue.

The cysts of $P$. saltonense differs from the cysthose of $P$. reticulatum, due to the $\underline{\text { in }}$ having a thick spongy-fibrous luxuria wall(vs. thin, fibrous luxuria), less developed distal ends of the processes, larger central its-body size-diameter $(48.6-70.9 \mu \mathrm{m}$ vs. $33-48 \mu \mathrm{m}$; $\underline{\text { Rochon et al., 1999), and generally shorter process length }(1.0-5.7 \mu \mathrm{m} \text { vs. typically } 7-14 \mu \mathrm{m} \text {; }}$ Rochon et al., 1999)(48.6 (56.3) $70.9 \mu \mathrm{m}(\mathrm{SD}=5.3, \mathrm{n}=23))$ for $P$. saltenense, as opposed to 33-48 um for $P$. reticulatum (Rochon et al., 1999) and its process length (1.0 (3.1) $5.7 \mu \mathrm{m}$ $(\mathrm{SD}=1.2, \mathrm{n}=66)$ ) for $P$. saltonense, as opposed to typical $7-14 \mu \mathrm{m}$ for $P$. reticulatum (Rochon et al., 1999); although the cysts of $P$. reticulatum shows very wide variationvary widely-sizes, with formation ofsome being completely bald eysts-(e.g., Mertens et al., 2012a; Jansson et al., 2014). 
Several-Numerous other Operculodinium species have been described and a detailed comparison is given bywe refer to Marret and Kim (2009) for their detailed comparison, as; none of these closely resembles the cysts of $P$. saltonense.

\subsection{Phylogenetics, evolution and position and relationships of Protoceratium,}

Pentaplacodinium, and Ceratocorys

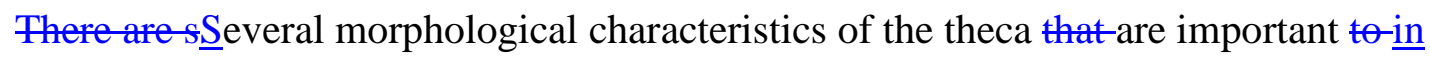
understanding the evolution of Protoceratium, Pentaplacodinium, and Ceratocorys the three genera in question-(Plate 7). The shape of the cover plate of Ceratocorys is more similar to that of the cover plate of Pentaplacodinium, but less similar to the sigmoidal cover plate of

\section{Protoceratium.}

Pentaplacodinium and Ceratocorys can be considered closer to Gonyaulax than

Protoceratium, because the anterior intercalary is always well-_separated from the apical pore plates, whilst whereas in Protoceratium reticulatum it is closer and has even been suggested to contact the apical pore plates (Hansen et al. 1997). However, It should however-be noted, $\underline{\text { however, that Protoceratium-reticulatum and Gonyaulax have six precingular plates, whereas }}$ whilst Ceratocorys and Pentaplacodinium have five-precingulars. So it is not surprising that in the molecular phylogenies, Pentaplacodinium has an intermediate position between

Ceratocorys and Protoceratium (Figs. 5-7); the relation to other gonyaulacoids at this time is unclear and further molecular studies of related genera are required, particularly to understand how to resolve the position of Protoceratium at family level. Another issue regards a conflict in the dual nomenclature: the cyst of $P$. reticulatum and $P$. saltonense both are considered to belong to the cyst-defined genus Operculodinium, whereas whilst the thecate stages belong to 
two different genera; further cyst_-theca experiments within this group of related species should help to understand how the genus-generic concepts can be made conformrationalized. In addition, the ITS marker was able to separate two large subclades within $P$. reticulatum: strains that are predominantly associated with warmer waters (Sub-clade 1A), and other strains largely associated with colder waters (Sub-clade 1B) (Fig. 7). Do these subclades reflect pseudocryptic speciation in Protoceratium reticulatum as previously suggested by Mertens et al. (2012a)?

Other morphological characteristics of the theca are conserved in Protoceratium, Pentaplacodinium, and Ceratocorys and other gonyaulacoids. For instance, there is no difference in overlap pattern between Protoceratium, Pentaplacodinium, Ceratocorys, Gonyaulax and Lingulodinium (Fig. 4).

\subsection{Biogeography and ecology of $\mathrm{P}$. saltonense}

According to the plankton observations, $P$. saltonense can be found in tropical to subtropical regions. We have not observed $P$. saltonense and $P$. reticulatum have not been observed in the same samples, which suggests that boththese species possibly-inhabit different niches, where $P$. saltonense has a preference for higher temperatures and salinities ${ }_{2}$ and $P$. reticulatum has a preference for somewhat lower temperatures and salinities. This difference would need to be established-quantified through culture experiments.

\subsection{Toxicity}

Strains identified as Pentaplacodinium saltonense (CCMP404, CCMP1720 and CCMP1721), have been identified as yessotoxin producers using fluorescence HPLC (Paz et al., 2004). A 
later toxin analysis by LC-MS of the same strains was negative (Paz et al., 2007), and the authors considered that these strains had lost their toxicity after a number of years in culture. The-_produced toxins produced by these strains of Pentaplacodinium saltonense are similar to toxins produced by strains we-identified as Protoceratium reticulatum, all of which are yessotoxin producers, such as strains from Chile (Alvarez et al., 2011), Jervis Inlet, British Columbia, Canada (Cassis, 2005), German Bight, the-North Sea (Röder et al., 2011, 2012), Okkirai Bay, Japan (Koike et al., 2006) and Spain (Paz et al., 2007, 2013). The presence of $P$. saltonense in the Salton Sea has been considered a potential causative agent of mortality events in the Salton Seaindicates that it is potentially toxic (Reifel et al., 2002, whom identified it as Protoceratium reticulatum). However, tTHowever, there have not however not been $n \oplus$ reports of toxic events knowingly involving $P$. saltonense.

Several other studies have investigated the toxicity of strains that they designate as Protoceratium reticulatum, but for which we could not verify the identifications could not be verified (e.g., Satake et al., 1999; Ciminiello et al., 2003; Samdal et al., 2004; Finch et al., 2005; Eiki et al., 2005; Mitrovic et al., 2005; Guerrini et al., 2007; Suzuki et al., 2007).

\section{Conclusions}

Pentaplacodinium saltonense gen. et sp. nov. is described from the Salton Sea (CA, USA).

The distinct cover plate (similar to Ceratocorys, but sigmoidal in Protoceratium), five precingular plates (also fiveas in Ceratocorys, but six in Protoceratium), the very narrow contact between 1' and Sa (wide contact in Protoceratium, no contact in Ceratocorys), a more roundish-rounded eell thecal shape, the displacement of the cingulum by two widths ( $\forall$ s. one width in Protoceratium), as well as the clear separation and distances seen in the three phylogenies, justifies the creation of a new genus. The chorate cysts of $P$. saltonense bear 
short processes often with parallel alignments. These cysts,-_correspond to the cyst-defined species-genus Operculodinium Wall 1967, and are most similar to $O$. israelianum and $O$. psilatum with short processes and often parallel alignments. The geographic distribution of mMotile stages of Pentaplacodinium saltonense wasare confirmed infrom four widely dispersed locations-and its distribution is thereforeis considered, suggesting a subtropical to tropical distribution for this species., and does not overlap with that of Protoceratium reticulatum and Pentaplacodinium saltonense are not known to inhabit the same environments. Similar toAs with the -yessotoxin-producing Protoceratium reticulatum, Pentaplacodinium saltonense is potentially a yessotoxin producer, as shown by previous studies.

Note added: While this paper has been going through the process of final acceptance to Harmful Algae, another study was accepted (Salgado et al., accepted) that addresses similar $\underline{\text { scientific questions. }}$

\section{Acknowledgements}

V.P. and M.J.H. each acknowledge support from a Discovery Grant of the Natural Sciences and Engineering Research Council of Canada (NSERC). K.B.A. and M.F. acknowledge-were supported from by the Instituto Nacional de Investigación y Tecnología Agraría y Alimentaria of the Spanish Government (project RTA2005-00109-00-00). We thank CINVESTAV, Merida is thanked for supplying information about the Yucatan samples. Beatriz Paz is acknowledged for interesting discussions on toxicity. We would like to thank-Anke Kremp, Maija Hutunnen, Jacob Larsen, Paul Hargraves and Ximena Vivanco are thanked forkindly providing provided plankton samples. Nancy Lewis and Margaret Beaton are thanked 
forgenerously sharing shared information on strains from Nova Scotia, Canada. We are gratefulThanks to -Captain Brown, crew of the MSV Strickland, Ms. Sarah Thornton ${ }_{2}$ and EOS313-2010 (University of Victoria) students are all thanked for their participation in sediment sample collection. Paul Hargraves is acknowledged forkindly providing provided SEM images of $P$. saltonense from cultures established from the Indian River Lagoon.

\section{References}

Adachi, M., Sako, Y., Ishida, Y., 1996. Analysis of Alexandrium (Dinophyceae) species using sequences of the 5.8S ribosomal DNA and internal transcribed spacer regions. J. Phycol. 32, $424-432$.

Al-Muftah, A.R., 1991. Dinoflagellates of Qatari Waters-waters (PhD thesis), vol. 2. University College of North Wales, Bangor University, pp. 261.

Alvarez, G., Uribe, E., Díaz, R., Braun, M., Mariño, C., Blanco, J., 2011. Bloom of the Yessotoxin producing dinoflagellate Protoceratium reticulatum (Dinophyceae) in Northern northern Chile. J. Sea Res. 64, 427-434.

Andree, K.B., Quijano-Scheggia, S.;.,Fernández, M., Elandaloussi, L.M., Garcés, E., Camp, J., Diogene, J._(2011_f Quantitative PCR Coupled coupled with Melt $\underline{\text { melt Curve-curve }}$ Analysis-analysis for Detection-detection of Selected selected Pseudonitzschia spp. (Bacillariophyceae) from the Northwesternnorthwestern Mediterranean Sea. App. and Env. Micro, 77(5) 1651-1659. 
875

876

877

878

879

880

881

882

883

884

885

886

887

888

889

890

891

892

893

894

895

896

Balech, E., 1980. On thecal morphology of dinoflagellates with special emphases-emphasis on circular and sulcal plates. Anales del Centro de Ciencias del Mar y Limnología, UNAM 7(1), $57-68$.

Balech, E., 1988. Los dinoflagellados del Atlantico sudoccidental. Publicaciones Especiales Instituto Español de Oceanografia 1, 1-310.

Below, R., 1987. Evolution und Systematik von Dinoflagellaten-Zysten aus der Ordnung

Peridiniales. I. Allgemeine Grundlagen und Subfamilie Rhaetogonyaulacoideae (Familie

Peridiniaceae). Palaeontographica, Abteilung B 205, 1-164.

Bergh, R.S., 1881. Der Organismus der Cilioflagellaten. Eine phylogenetische Studie.

Morphologisches Jahrbuch 7(2), 177-288.

Bogus, K. Mertens, K.N., Lauwaert, J., Harding, I.C., Vrielinck, H., Zonneveld, K.A.F.,

Versteegh, G.J.M., 2014. Differences in the chemical composition of organic-walled

dinoflagellate resting cysts from phototrophic and heterotrophic dinoflagellates. J. Phycol. 50, $254-266$.

Bolch, C.J.S., 1997. The use of polytungstate for the separation and concentration of living dinoflagellate cysts from marine sediments. Phycologia 37, 472-478.

Braarud, T., 1945. Morphological observations on marine dinoflagellate cultures (Porella perforata, Goniaulax tamarensis, Protoceratium reticulatum). Avh. Utgit. Nor. Vidensk. Akad. Oslo Mat.-Naturvidensk. K1. 11, 1-18. 
898 Bütschli, O. 1885. Erster Band. Protozoa. 3. Unterabtheilung (Ordnung) Dinoflagellata. In: 899 Dr. H.G. Bronn's Klassen und Ordnungen des Thier-Reichs, wissenschaftlich dargestellt in

Wort und Bild. C.F. Winter'sche Verlagshandlung, Leipzig und Heidelberg. p. 906-1029.

901

902 Cassis, D., 2005. The effect of harmful algae on the summer mortality of juvenile Pacific

903 Oysters-oysters (Crassostrea gigas). MSc. Thesis, University of British Columbia, 73 pp.

904

905

Ciminiello, P., Dell’ Aversano, C., Fattorusso, E., Forino, M., Magno, S., Guerrini, F.,

Pistocchi, R., Boni, L. 2003. Complex yessotoxins profile in Protoceratium reticulatum from

north-western Adriatic sea revealed by LC-MS analysis. Toxicon 42, 7-14.

908

909

Claparède, E., Lachmann, J., 1858. Etudes sur les infusoires et les rhizopodes. Mem. Inst. Nat.

910

Genev. 6, 261-482.

911

912

Dale, B., 1983. Dinoflagellate resting cysts: “_"benthic plankton”-". In: Fryxell, G.A. (ed.),

Survival Strategies of the Algae, Cambridge University Press, Cambridge, U.K., pp.69-136.

914

915

Dale, B., 1996. Dinoflagellate cyst ecology: modelling and geological applications. In:

Jansonius, J., McGregor, D.C. (eds.), Palynology: Principles and Applications. Volume 3.

917 American Association of Stratigraphic Palynologists Foundation, Dallas, Texas, pp. 1249-

$918 \quad 1275$.

919

920

Daugbjerg, N., Hansen, G., Larsen, J., Moestrup, Ø., 2000. Phylogeny of some of the major 
922 including the erection of three new genera of unarmoured dinoflagellates. Phycologia 39,

$923 \quad 302-317$.

924

925

Deflandre, G., Cookson, I.C., 1955. Fossil microplankton from Australian Late Mesozoic and

Tertiary sediments. Australian Journal of Marine and Freshwater Research 6, 242-313.

927

928

Dodge, J.D., 1989. Some revisions of the family Gonyaulaceae (Dinophyceae) based on a scanning electron microscope study. Bot. Mar. 32, 275-298.

930

Eiki, K., Satake, M., Koike, K., Ogata, T., Mitsuya, T., Oshima, Y., 2005. Confirmation of yessotoxin production by the dinoflagellate Protoceratium reticulatum in Mutsu Bay. Fish. Sci. 71, 633-638.

934

935

Faust, M.A., Litaker, R.W., Vandersea, M.W., Kibler, S.R., Tester, P.A. 2005. Dinoflagellate

diversity and abundance in two Belizean coral-reef mangrove lagoons: a test of Margalef's

937 mandala. Atoll Research Bulletin 534, 105-132.

938

Fensome, R.A., Gocht, H., Stover, L.E., Williams, G.L., 1993a. The Eisenack Catalog of

Verlagsbuchhandlung, Stuttgart, Germany.

Fensome, R., Taylor, F., Norris, G., Sarjeant, W., Wharton, D., Williams, G., 1993ㅁ․ A 245. 
949

950

951

952

953

954

955

956

957

958

959

960

961

962

963

964

965

966

967

968

969

Ferrari, R.L., Weghorst, P., 1997. Salton Sea 1995 hydrographic GPS survey. U.S. Bureau of

Reclamation, Water Resources Services. Denver, Colorado, 23 pp.

Finch, S.C., Wilkins, A.L., Hawkes, A.D., Jensen, D.J., MacKenzie, A.L., Beuzenberg, V.,

Quilliam, M.A., Olseng, C.D., Samdal, S.A., Aasen, J., Selwood, A.I., Cooney, J.M., Sandvik, M., Miles, C.O., 2005. Isolation and identification of (44-R,S)-44,55-dihydroxyyessotoxin from Protoceratium reticulatum, and its occurrence in extracts of shellfish from New Zealand, Norway and Canada. Toxicon 46, 160-170.

Gómez, F., 2012. A checklist and classification of living dinoflagellates (Dinoflagellata, Alveolata). CICIMAR Océanides 27(1), 65-140.

Guerrini, F., Ciminiello, P., Dell'Aversano, C., Tartaglione, L., Fattorusso, E., Boni, L., Pistocchi, R., 2007. Influence of temperature, salinity and nutrient limitation on yessotoxin production and release by the dinoflagellate Protoceratium reticulatum in batch-cultures. Harmful Algae 6, 707-717.

Guillou, L., Nezan, E., Cueff-Gauchard, V., Barbier, G., 2002. Genetic diversity and molecular detection of three toxic dinoflagellate genera (Alexandrium, Dinophysis and Karenia) from French coasts. Protist. 153, 223-238

Hall, T.A-.., 1999. BioEdit: a user-friendly biological sequence alignment editor and analysis

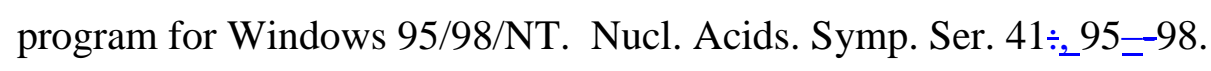

970 
Hansen, G., Moestrup, Ø. and Roberts, K.R., 1997. Light and Electron-electron Micrescepical microscopical Observations observations on Protoceratium reticulatum (Dinophyceae). Arch. Protistenk. 147, 381-391.

Hansen, G., Daugbjerg, N., Henriksen, P., 2000. Comparative study of Gymnodinium mikimotoi and Gymnodinium aureolum, comb. nov. (= Gyrodinium aureolum) based on morphology, pigment composition, and molecular data. J. Phycol., 36, 394- 410.

Head, M.J., Wrenn, J.H. (eds.), 1992. A forum on Neogene-Quaternary dinoflagellate cysts: The edited transcript of a round table discussion held at the Second Workshop on Neogene dinoflagellates. In: Head, M.J., Wrenn, J.H. (eds.), Neogene and Quaternary Dinoflagellate Cysts and Acritarchs. American Association of Stratigraphic Palynologists Foundation, Dallas, Texas, pp. 1-31.

Head, M.J., 1996a . Modern dinoflagellate cysts and their biological affinities. In: Jansonius, J., McGregor, D.C. (eds.), Palynology: principles and applications. American Association of Stratigraphic Palynologists Foundation, Dallas, Texas, vol. 3, pp. 1197-1248.

Head, M.J., 1996b. Late Cenozoic dinoflagellates from the Royal Society borehole at Ludham, Norfolk, eastern England. J. Paleontol. 70, 543-570.

Head, M.J., 1997. Thermophilic dinoflagellate assemblages from the mid Pliocene of eastern England. J. Paleontol. 71, 165-193. 
Hennissen, J.A.I., Head, M.J., De Schepper, S., Groeneveld, J., 2017. Dinoflagellate cyst paleoecology during the Pliocene-Pleistocene climatic transition in the North Atlantic. Palaeogeogr., Palaeoclimatol., Palaeoecol. 470, 81-108.

Holdren, G.C., Montaño, A., 2002. Chemical and physical characteristics of the Salton Sea, California. Hydrobiol. 473, 1-21.

Howard, M.D.A., Smith, G.J., Kudela, R.M., 2009. Phylogenetic relationship of yessotoxinproducing dinoflagellates based on the Large Subunit and Internal Transcribed Spacer

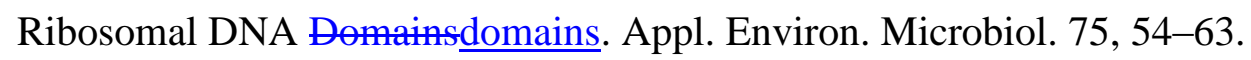

Jansson, I.-M., Mertens, K.N., Head, M.J. with contributions from de Vernal, A., Londeix, L., Marret, F., Matthiessen, J., Sangiorgi, F., 2014. Statistically assessing the correlation between salinity and morphology in cysts produced by the dinoflagellate Protoceratium reticulatum from surface sediments of the North Atlantic Ocean, Mediterranean-Marmara-Black Sea region, and Baltic-Kattegat-Skagerrak estuarine system. Palaeogeogr. Palaeoclimatol. Palaeoecol. 399, 202-213.

Kofoid, C.A., 1907. Reports on the scientific results of the expedition to the eastern tropical Pacific, in charge of Alexander Agassiz, by the U.S. Fish Commission steamer_"AAlbatross“, ”, from October, 1904, to March, 1905, Lieut-_. Commander L.M. Garrett, U.S.N., commanding. IX. New species of dinoflagellates. Bull. Mus. Comp. Zool. 50(6), 163-207. 
Steamer “-_AlbatrossALBATROSS"“-, from October 1904, to March, 1906, Lieut. L.M.

Garrett, U.S.N., Commanding. XXII. New genera and species of

Binøflagellatesdinoflagellates. Bull. Mus. Comp. Zool. 54(7), 267-302.

Koike, K., Horie, Y., Suzuki, T., Kobiyama, A., Kurihara, K., Takagi, K., Kaga, S.N.,

Oshima, Y., 2006. Protoceratium reticulatum in northern Japan: environmental factors associated with seasonal occurrence and related contamination of yessotoxin in scallops. J. Plankton Res. 28, 103-112.

Lane, D. J.2 1991. 16S/23S sequencing. In: Nucleic Acid Technologies in Bacterial Systematic. Stackebrandt E, Goodfellow M (Eds) pp. 115-175, Wiley, NY.

Marret, F., Kim, S.-Y., 2009. Operculodinium aguinawense sp. nov., a dinoflagellate cyst from the late Pleistocene and recent sediments of the east Equatorial Atlantic ocean.

Palynology 33, 125-139.

Matsuoka, K., McMinn, A., Wrenn, J.H., 1997. Restudy of the Holotype of Operculodinium centrocarpum (Deflandre \& Cookson) Wall (Dinophyceae) from the Miocene of Australia, and the Taxonomy taxonomy of Related related Speciesspecies. Palynology 21, 19-33.

Medlin, L. K, Elwood, H. J., Stickel, S., Sogin, M. L.2 1988. The characterization of enzymatically amplified eukaryotic 16S-like rRNA-coding regions. Gene--71, 491-499.

Mertens, K.N., Ribeiro, S., Bouimetarhan, I., Caner, H., Combourieu Nebout, N., Dale, B., de Vernal, A., Ellegaard, M., Filipova, M., Godhe, A., Goubert, E., Grøsfjeld, K., Holzwarth, U., 
Kotthoff, U., Leroy, S.A.G., Londeix, L., Marret, F., Matsuoka, K., Mudie, P.J., Naudts, L., Peña-Manjarrez, J.L., Persson, A., Popescu, S.-M., Pospelova, V., Sangiorgi, F., van der Meer, M., Vink, A., Zonneveld, K.A.F., Vercauteren, D., Vlassenbroeck, J., Louwye, S., 2009. Process length variation in cysts of a dinoflagellate, Lingulodinium machaerophorum, in surface sediments: Investigating its potential as salinity proxy. Mar. Micropaleontol. 70, 54-69.

Mertens, K.N., Dale, B., Ellegaard, M., Jansson, I.-M., Godhe, A., Kremp, A., Louwye, S., 2011. Process length variation in cysts of the dinoflagellate Protoceratium reticulatum, from surface sediments of the Baltic-Kattegat-Skagerrak estuarine system: a regional salinity proxy. Boreas 40, 242-255.

Mertens, K.N., Bringué, M., Van Nieuwenhove, N., Takano, Y., Pospelova, V., Rochon, A., de Vernal, A., Radi, T., Dale, B., Patterson, R.T., Weckström, K., Andrén, E., Louwye, S., Matsuoka, K., 2012a. Process length variation of the cyst of the dinoflagellate Protoceratium reticulatum in the North Pacific and Baltic-Skagerrak region: calibration as an annual density proxy and first evidence of pseudo-cryptic speciation. J. Quaternary Sci. 27, 734-744.

Mertens, K.N., Price, A., Pospelova, V., 2012b. Determining the absolute abundance of dinoflagellate cysts in recent marine sediments II: further tests of the Lycopodium markergrain method. Rev. Palaeobot. Palynol. 184, 74-81.

Mertens, K.N., Wolny, J., Carbonell-Moore, C., Bogus, K., Ellegaard, M., Limoges, A., de Vernal, A., Gurdebeke, P., Omura, T., Mohd. A Al-Muftah, A., Matsuoka, K., 2015. Taxonomic re-examination of the toxic armoured dinoflagellate Pyrodinium bahamense Plate 
1906: can morphology or LSU sequencing separate $P$. bahamense var. compressum from var. bahamense? Harmful Algae 41, 1-24.

Meunier A., 1910. Microplancton des mers de Barents \& de Kara. In: Duc d_-'Orléans Campagne Arctique de 1907. Bulens, Bruxelles, 355 pp.

Mitrovic, S.M., Hamilton, B., McKenzie, L., Furey, A., James, K.J., 2005. Persistence of yessotoxin under light and dark conditions. Mar. Environ. Res. 60, 397-401.

Morquecho, L., Góngora-González, D.T. \& Okolodkov, Y.B. 2009. Cyst-theca relationships of Gonyaulacales and Peridiniales (Dinophyceae) from Bahía Concepción, Gulf of California. Acta Botanica Mexicana 88, 9-29.

Murray, G., Whitting, F.G., 1899. New Peridiniaceae from the Atlantic. Trans. Linn. Soc. Lond., Bot. 5, 321-342.

Paez-Reyes, M., Head, M.J., 2013. The Cenozoic Gonyaulacaceangonyaulacacean Dinoflagellate-dinoflagellate Generagenera Operculodinium Wall, 1967 and Protoceratium Bergh, 1881 and Their their Phylogenetic phylogenetic Relationshipsrelationships. J. Paleo. 87(5), 786-803.

Paz, B., Riobó, P., Fernández, M.L., Fraga, S., Franco, J.M., 2004. Production and release of yessotoxins by the dinoflagellates Protoceratium reticulatum and Lingulodinium polyedrum in culture. Toxicon 44, 251-258. 
Paz, B., Riobó, P., Ramilo, I., Franco, J.M., 2007. Yessotoxins profile in strains of

Protoceratium reticulatum from Spain and USA. Toxicon 50, 1-17.

Paz, B., Daranas, A.H., Norte, M., Riobó, P., Franco, J.M., Fernández, J.J., 2008.

Yessotoxins, a Group-group of Marine-marine Polyether-polyether Foxinstoxins: an Overviewoverview. Mar. Drugs 6, 73-102.

Paz, B., Blanco, J., Franco, J.M., 2013. Yessotoxins production during the culture of Protoceratium reticulatum strains isolated from Galician Rias Baixas (NW Spain). Harmful algae 21-22, 13-19.

Pospelova, V., Esenkulova S., Johannessen S.C., O'Brien-0’Brien M. C.\&_, Macdonald R.W.2 2010. Organic-walled dinoflagellate cyst production, composition and flux from 1996 to 1998 in the central Strait of Georgia (BC, Canada): a sediment trap study. Mar.

Micropaleontol. $75 \div$, $17-37$.

Reifel, K.M., McCoy, M.P., Rocke, T.E., Tiffany, M.A., Hurlbert, S.H., Faulkner, D.J., 2002. Possible importance of algal toxins in the Salton Sea, California. Hydrobiologia 473, 275292.

Reinecke, P., 1967. Gonyaulax grindleyi sp. nov.: a dinoflagellate causing a red tide at Elands Bay, Cape Province in December 1966. S. Afr. J. Bot. 33, 157-160.

Rochon, A., de Vernal, A., Turon, J.-L., Matthiessen, J., Head, M.J., 1999. Distribution of Recent recent dinoflagellate cysts in surface sediments from the North Atlantic Ocean and 
adjacent areas in relation to sea-surface parameters. American Association of Stratigraphic Palynologists, Contributions Series, no. 35, 146 p.

Röder, K., Fritz, N., Gerdts, G., Luckas, B., 2011. Accumulation and Depuration-depuration of Yessotoxin-yessotoxin in Two-two Bivalvesbivalves. J. Shellfish Res. 30, 167-175.

Röder, K.,Hantzsche, F.M., Gebühr, C., Miene, C., Helbig, T., Krock, B., Hoppenrath, M., Luckas, B., Gerdts, G., 2012. Effects of salinity, temperature and nutrients on growth, cellular characteristics and yessotoxin production of Protoceratium reticulatum. Harmful Algae 15, 59-70.

Rossignol, M., 1964. Hystrichosphères du Quaternaire en Méditerranée orientale, dans les sédiments Pléistocènes et les boues marines actuelles. Revue de micropaléontologie 7, 83-99.

Sala-Pérez, M., Alpermann, T.J., Krock, B., Tillmann, U., 2016. Growth and bioactive secondary metabolites of arctic Protoceratium reticulatum (Dinophyceae). Harmful Algae 55, 85-96.

Saldarriaga, J.F., Taylor, F.J.R., Cavalier-Smith, T., Menden-Deuer, S., Keeling, P.J., 2004. Molecular data and the evolutionary history of dinoflagellates. Eur. J. Protistol. 40, 85-111. Salgado, P., Figueroa, R.I., Ramilo, I., Bravo, I., 2017. The life history of the toxic marine dinoflagellate Protoceratium reticulatum (Gonyaulacales) in culture. Harmful Algae 68, 6781. 
$\underline{\text { Salgado, P., Fraga, S., Rodríguez, F., Riobó, P., accepted. Ceratocorys mariaovidiorum sp. }}$ nov. (Gonyaulacales), a new dinoflagellate species previously reported as Protoceratium reticulatum. Journal of Phycology, accepted.

Samdal, I.A., Naustvoll, L.J., Olseng, C.D., Briggs, L.R., Miles, C.O., 2004. Use of ELISA to identify Protoceratium reticulatum as a source of yessotoxin in Norway. Toxicon 44, 75-82.

Satake, M., Ichimura, T., Sekiguchi, K., Yoshimatsu, S., Oshima, Y. 1999. Confirmation of Yessotoxin and 45,46,47-Trinoyessotoxin production by Protoceratium reticulatum collected in Japan. Natural toxins 7, 147-150.

Schiller, J., 1937. Dinoflagellatae (Peridineae) in monographischer Behandlung. In: Dr. L. Rabenhorst's Kryptogamen-Flora von Deutschland, Österreich und der Schweiz. Bd. 10(3). Teil 2(3), pp. 321-480.

Scholin, C.A., Herzog, M., Sogin, M., Anderson, D.M. 1994. Identification of group- and strain-specific genetic markers for globally distributed Alexandrium (Dinophyceae). II. Sequence analysis of a fragment of the LSU rRNA gene. J. Phycol. 30, 999-1011.

Steidinger K.A. \& J. Williams (1970) Dinoflagellates. Memoirs of the Hourglass Cruises 2, 1-251. Published by Marine Research Laboratory, Florida Department of Natural Resources, $\underline{\text { St. Petersburg, Florida. }}$ 
Stein, F. von, 1883. Der Organismus der Infusionsthiere. 3. Abt. Der Organismus der Arthrodelen Flagellaten nach eigenen Forschungen in systematischer Reihenfolge bearbeitet.

2. Hälfte. Einleitung und Erklärung der Abbildungen, W. Engelmann, Leipzig, pp. 1-30.

Stosch, H.A. von, 1969. Dinoflagellaten aus der Nordsee I. Über Cachonina niei Loeblich (1968), Gonyaulax grindleyi Reinecke (1967) und eine Methode zur Darstellung von Peridineenpanzern. Helgoländ. Wiss. Meer. 19, 558-568.

Suzuki, T., Horie, Y., Koike, K., Satake, M., Oshima, Y., Iwataki, M., Yoshimatsu, S., 2007. Yessotoxin analogues in several strains of Protoceratium reticulatum in Japan determined by liquid chromatography-hybrid triple quadrupole/linear ion trap mass spectrometry. Journal of Chromatography A 1142, 172-177.

Takano, Y., Horiguchi, T., 2004. Surface ultrastructure and molecular phylogenetics of four unarmoured heterotrophic dinoflagellates, including the type species of the genus Gyrodinium (Dinophyceae). Phycol. Res. 52, 107-116.

Takano, Y., Horiguchi, T. 2006. Acquiring scanning electron microscopical, light microscopical and multiple gene sequence data from a single dinoflagellate cell. J. Phycol. 42, $251-256$.

Tamura, K., Stecher, G., Peterson, D., Filipski, A., Kumar, S. 2013 MEGA6: Molecular Evolutionary Genetics Analysis Version 6.0. Mol Biol Evol. 30: 2725_-2729 
Tiffany, M.A., González, M.R., Swan, B.K., Reifel, K.M., Watts, J.M., Hurlbert, S.H. 2007. Phytoplankton dynamics in the Salton Sea, California, 1997-1999. Lake and Reservoir

Management 23, 582-605.

Wall, D., 1967. Fossil microplankton in deep-sea cores from the Caribbean Sea.

Palaeontology 10, 95-123.

Wall, D., Dale, B., 1966. "Living fossils” in western Atlantic plankton. Nature 211 (5053), $1025-1026$.

Wall, D., Dale, B., 1968. Modern dinoflagellate cysts and evolution of the Peridiniales.

Micropaleontology 14, 265-304.

Watts, J.M., Swan, B.K., Tiffany, M.A., Hurlbert, S.H., 2001. Thermal, mixing and oxygen regimes of the Salton Sea, California, 1997-1999. Hydrobiol. 162, 159-176.

Wołoszyńska, J., 1929. Dinoflagellatae Polskiego Baltyku i blot nad Piasnica. Archivum Hydrobiologji i Rybactwa 3, 153-278 [In Polish].

\section{Yamaguchi, A., Yoshimatsu, S., Hoppenrath, M., Wakeman, K.C., Kawai, H. 2016.}

Molecular phylogeny of the benthic dinoflagellate genus Amphidiniopsis and its relationships with the family Protoperidiniaceae. Protist. 167, 568_-583.

Zonneveld, K.A.F., Marret, F., Versteegh, G.J.M., Bogus, K., Bonnet, S., Bouimetarhan, I., Crouch, E., de Vernal, A., Elshanawany, R., Edwards, L., Esper, O., Forke, S., Grøsfjeld, K., 
1217 Henry, M., Holzwarth, U., Kielt, J.-F., Kim, S.-Y., Ladouceur, S., Ledu, D., Chen, L.,

1218 Limoges, A., Londeix, L., Lu, S.-H., Mahmoud, M.S., Marino, G., Matsouka [sic], K.,

1219 Matthiessen, J., Mildenhal [sic], D.C., Mudie, P., Neil, H.L., Pospelova, V., Qi, Y., Radi, T.,

1220 Richerol, T., Rochon, A., Sangiorgi, F., Solignac, S., Turon, J.L., Verleye, T., Wang, Y.,

1221 Wang, Z., Young, M., 2013. Atlas of modern dinoflagellate cyst distribution based on 2405

1222 datapoints. Rev. Palaeobot. Palynol. 191, 1-197.

1223 
Figure 1. Sites of studied plankton samples and cultured strains containing thecate stages of Pentaplacodinium saltonense (in red) and Protoceratium reticulatum (in blue). The locations are listed in Table 1.

Figure 2. Line drawings of extant members of the subfamily Cribroperidinioideae in dorsal view to show the dextral torsion typical of these gonyaulacoids. A. Pentaplacodinium saltonense. B. Protoceratium reticulatum. C. Lingulodinium polyedra. Labeling of tabulation follows a modified Kofoid system that recognizes homologs. anterior sulcal plate; Sda: right anterior sulcal plate; Sdp: right posterior sulcal plate; Ssa: anterior left sulcal plate; Ssp: posterior left sulcal plate; Sp: posterior sulcal plate; c: cingular plates.

Figure 4. Line drawings of epithecal overlapping plate patterns of gonyaulacoids discussed in this paper. Arrows indicate direction of overlap. A. Pentaplacodinium saltonense. B. Gonyaulax spinifera.

Figure 5. Neighbour-joining tree of $P$. reticulatum, $P$. saltonense and related strains sequenced in this study and sequences from Genbank based on an $80 \mathrm{bp}$ alignment of the V9 region of the SSU gene. Bootstrap values were retrieved from 1000 replicates and those $>70 \%$ are indicated at the nodes for neighbour-joining and maximum likelihood respectively. 
1249 Strain names are indicated followed by their geographic origin and accession number 1250 (Genbank).

Figure 6. Neighbour-joining tree of $P$. reticulatum, $P$. saltonense and related strains sequenced in this study and sequences from Genbank based on a 571 bp alignment of the V4 region of the LSU gene. Bootstrap values were retrieved from 1000 replicates and those $>70 \%$ are indicated at the nodes for neighbour-joining and maximum likelihood respectively. Strain names are indicated followed by their geographic origin and accession number (Genbank).

Figure 7. Neighbour-joining tree of $P$. reticulatum, $P$. saltonense and related strains sequenced in this study and sequences from Genbank based on a 356 bp alignment of the ITS 1-2 region. Bootstrap values were retrieved from 1000 replicates and those $>70 \%$ are indicated at the nodes for neighbour-joining and maximum likelihood respectively. Strain names are indicated followed by their geographic origin and accession number (Genbank).

\section{Plate Captions}

Plate 1. Light microscope images of Pentaplacodinium saltonense based on cyst-theca experiment from the Salton Sea. A. Living cyst from the Salton Sea St. 1. B-F. Germinated cyst from St. 2 (culture 2E3 used for single-cell PCR). B. Cross section, showing attached

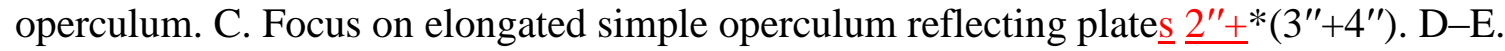
Focus on archeopyle, after removal of operculum. F. Cross section showing processes. G-I. 
archeopyle reflecting plate $*\left(3^{\prime \prime}+4^{\prime \prime}\right)$, showing attached operculum. H. Focus on operculum. I. Cross section, showing opened operculum. Scale bars $=20 \mu \mathrm{m}$.

Plate 2. Light microscope images of cyst-theca experiment from the Salton Sea. A-I. Images of living cells of Pentaplacodinium saltonense germinated from cyst depicted in Plate 1, Figs. B-F (culture 2E3). A. Globular cell. B. Angular cell. C. Fusiform cell. D. Epitheca. E. Hypotheca. F. Ventral view showing configuration of apical plates. G-I. Sulcal plates. Scale bars $=20 \mu \mathrm{m}$.

Plate 3. Scanning electron microscope images of Pentaplacodinium saltonense, all different cells from the Salton Sea, except D. A. Holotype. Ventral view. Arrowhead points to ventral pore between plates $1^{\prime}$ and $* 4$ '. Arrow shows flange on plate $1 \mathrm{p}$. B. Apical view, missing the cover plate. Small arrowhead points to small pores inside the thecal pores. Large arrowhead points to ventral pore between plates $1^{\prime}$ and $* 4^{\prime}$. Small arrowhead points to the three minute pores inside most pores. C. Dorsal view, showing dextral torsion. Note the cell roundness. D. Sulcal plates of a cell from culture SSCAP K-1479 (Indian River Lagoon, Florida). Arrowhead shows the narrow point of contact between the Sa and 1' plates. E. Antapical view. Scale bars A-C, E = $10 \mu \mathrm{m} ; \mathrm{D}=5 \mu \mathrm{m}$.

Plate 4. Scanning electron microscope images of Pentaplacodinium saltonense from the Indian River Lagoon. A. Apical view of a cell from culture SSCAP K-1479. Arrowhead points to ventral pore between plates $1^{\prime}$ and $* 4^{\prime}$. B. Same specimen as in A. Ventral view. Arrowhead points to ventral pore between plates $1^{\prime}$ and $* 4^{\prime}$. C. A different cell from a plankton sample courtesy of Paul Hargraves. Ventral view. Arrowhead points to ventral pore between plates $1^{\prime}$ and $* 4^{\prime}$. Arrow shows flange on plate $1 p$. D. Ventral view of a cell from a 
culture established by Paul Hargraves. E. Antapical view of a cell from the same culture as in D. E. Apical view of a cell from the same culture as in D. D-F: SEMs by Paul Hargraves. Scale bars $=10 \mu \mathrm{m}$.

Plate 5. Scanning electron microscope images of cysts of Pentaplacodinium saltonense extracted from Salton Sea sediment (St. 2) using palynological methods. A-C. Views showing shape of archeopyle, reflecting plate $*\left(3^{\prime \prime}+4^{\prime \prime}\right)$. D. Specimen that is torn along the cingulum. E. Specimen showing alignment of processes along the cingulum. F. Specimen with relatively large openings in cyst wall. G. Specimen with distinct intratabular processes. H. Specimen with relatively coarsely reticulated wall surface. I. Internal view of smooth cyst wall. Scale bars $=10 \mu \mathrm{m}$.

Plate 6. Scanning electron microscope images of cysts of Pentaplacodinium saltonense formed in culture of strain 3243 (Indian River Lagoon). A. Specimen showing preformed archeopyle and margins of principal archeopyle suture with reduced ornament. B. Specimen with attached thecal plate. C. Specimen with partly developed processes. D. Specimen with processes clearly reflecting tabulation. E. Specimen with preformed archeopyle. F. Specimen showing reflection of the sulcus. G-H. Specimen with well-developped wall texture. I. Wall texture of specimen with 'spider-web' microreticulation. Scale bars $=10 \mu \mathrm{m}$, except $\mathrm{H}, \mathrm{I}$, scale bars $=1 \mu \mathrm{m}$

Plate 7. Scanning electron microscope images of Protoceratium reticulatum cells and of the apical pore plates of the gonyaulacoids discussed in this study. A. Protoceratium reticulatum. Cell from Greenland, ventral view. B. Same cell in apical view. C. Protoceratium reticulatum. Cell from Elands Bay, South Africa. Dorsal view, note the dextral torsion. D. Apical pore 
1323 plates of a different cell of Protoceratium reticulatum (Greenland). E. Apical pore plates of a

1324 cell of Ceratocorys horrida (Central equatorial Pacific). F. Apical pore plates of a cell of

1325 Pentaplacodinium saltonense from culture SSCAP K-1479 (Indian River Lagoon). G. Apical

1326 pore plates of a cell of Ceratocorys gourretii. H. Apical pore plates of another cell of

1327 Pentaplacodinium saltonense from culture SSCAP K-1479 (Indian River Lagoon). Scale bars

1328 $\mathrm{A}-\mathrm{C}=10 \mu \mathrm{m} ; \mathrm{D}-\mathrm{H}=5 \mu \mathrm{m}$.

1329 


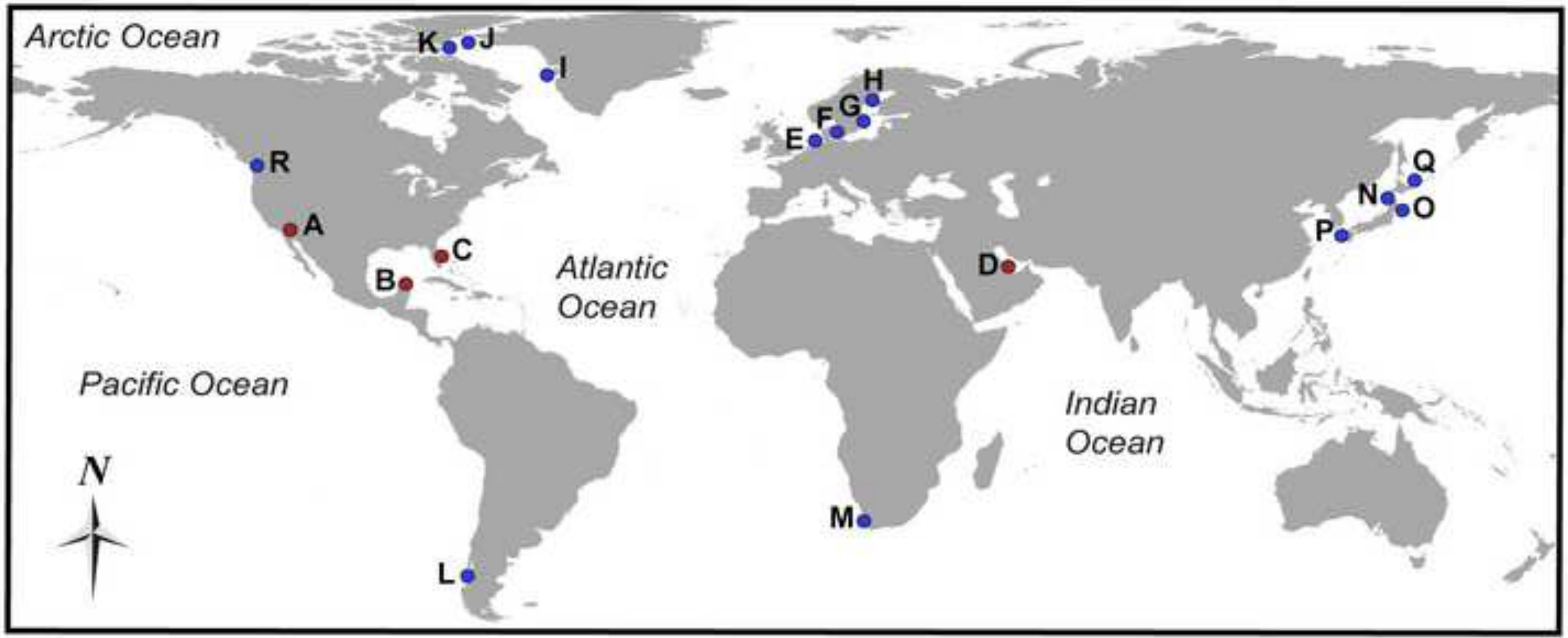


Figure 2

Click here to download high resolution image
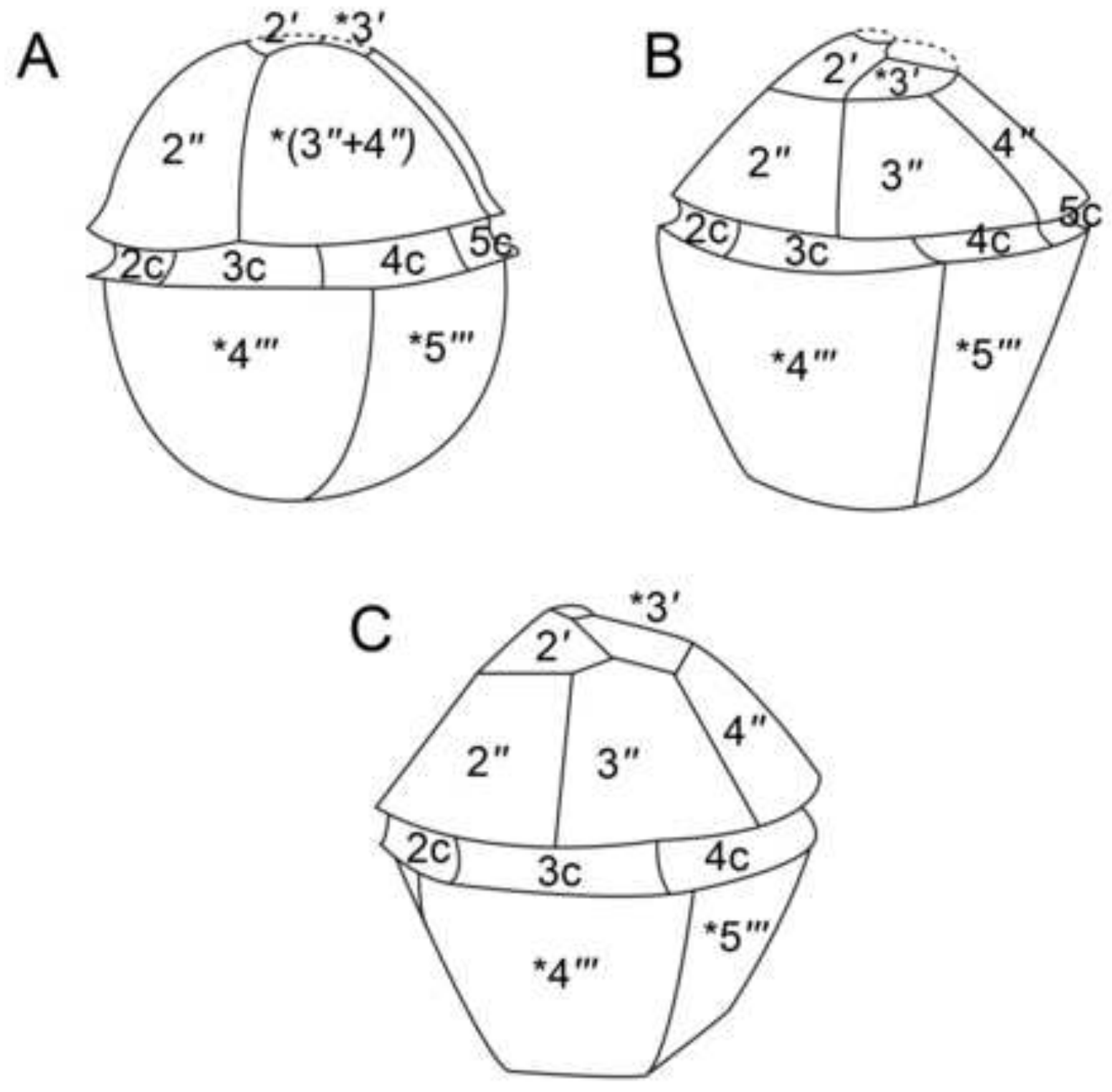
Figure 3

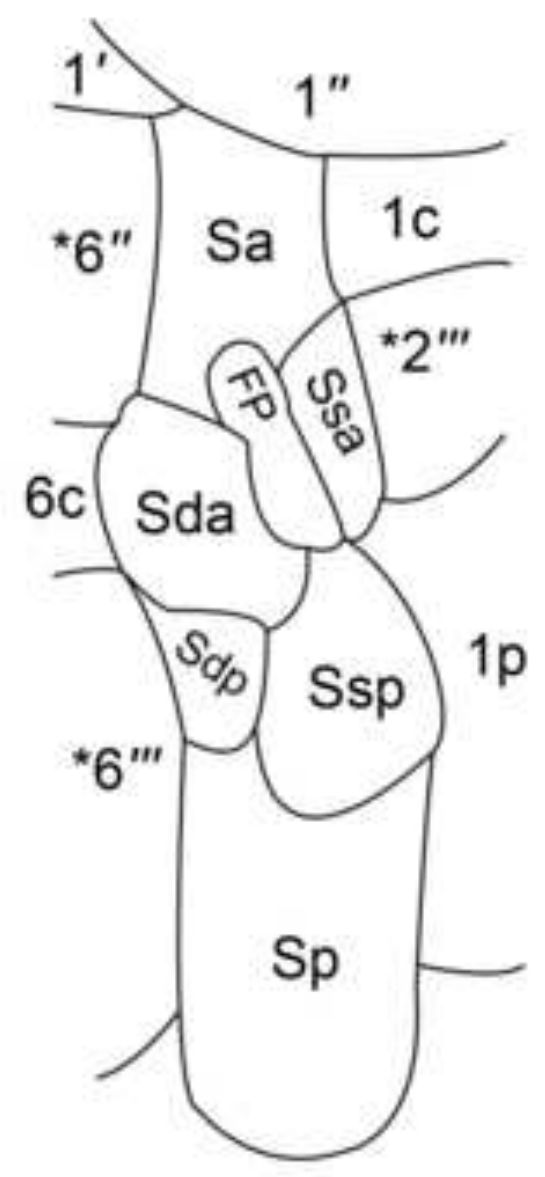


Figure 4

Click here to download high resolution image

A

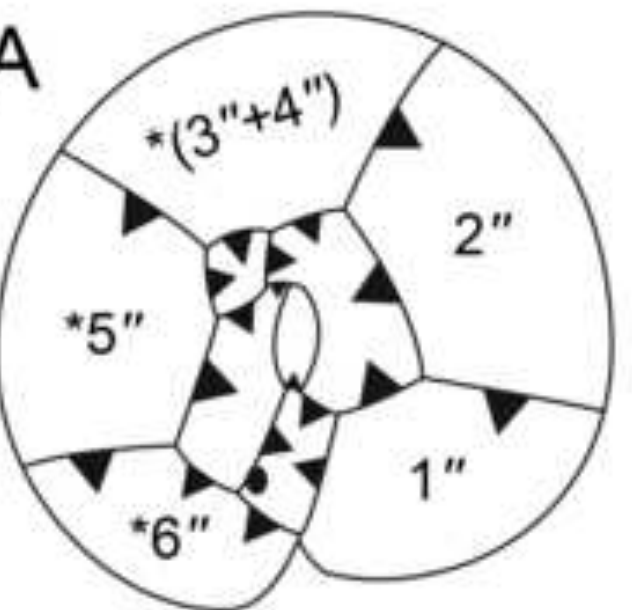

B

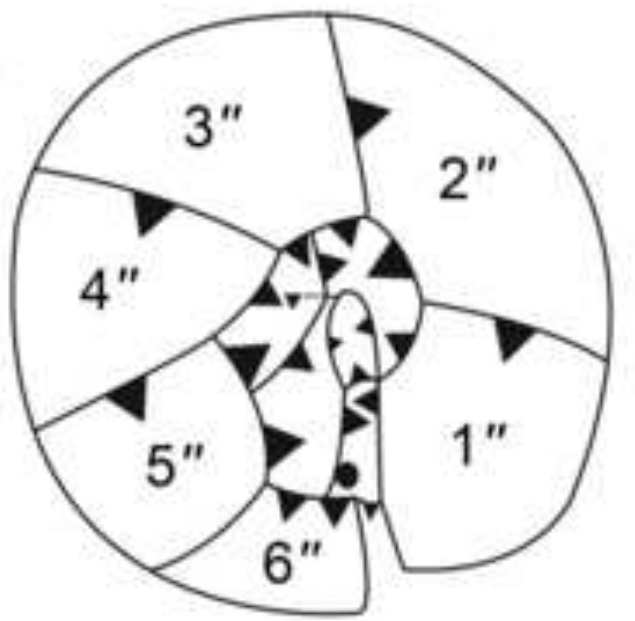

C

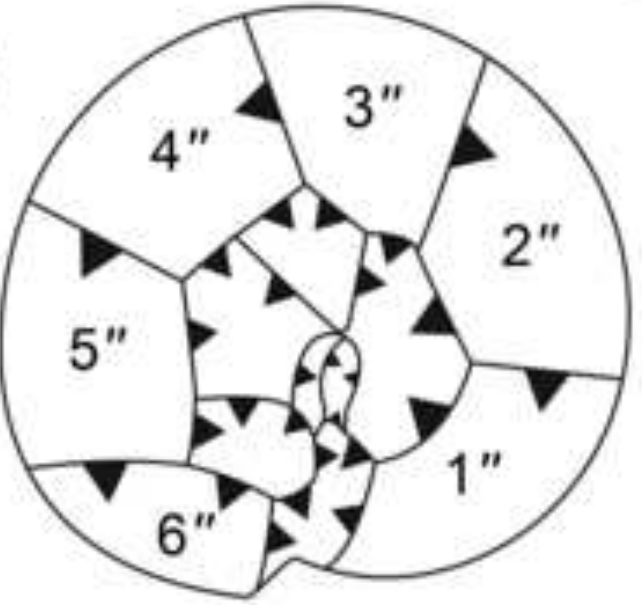

D
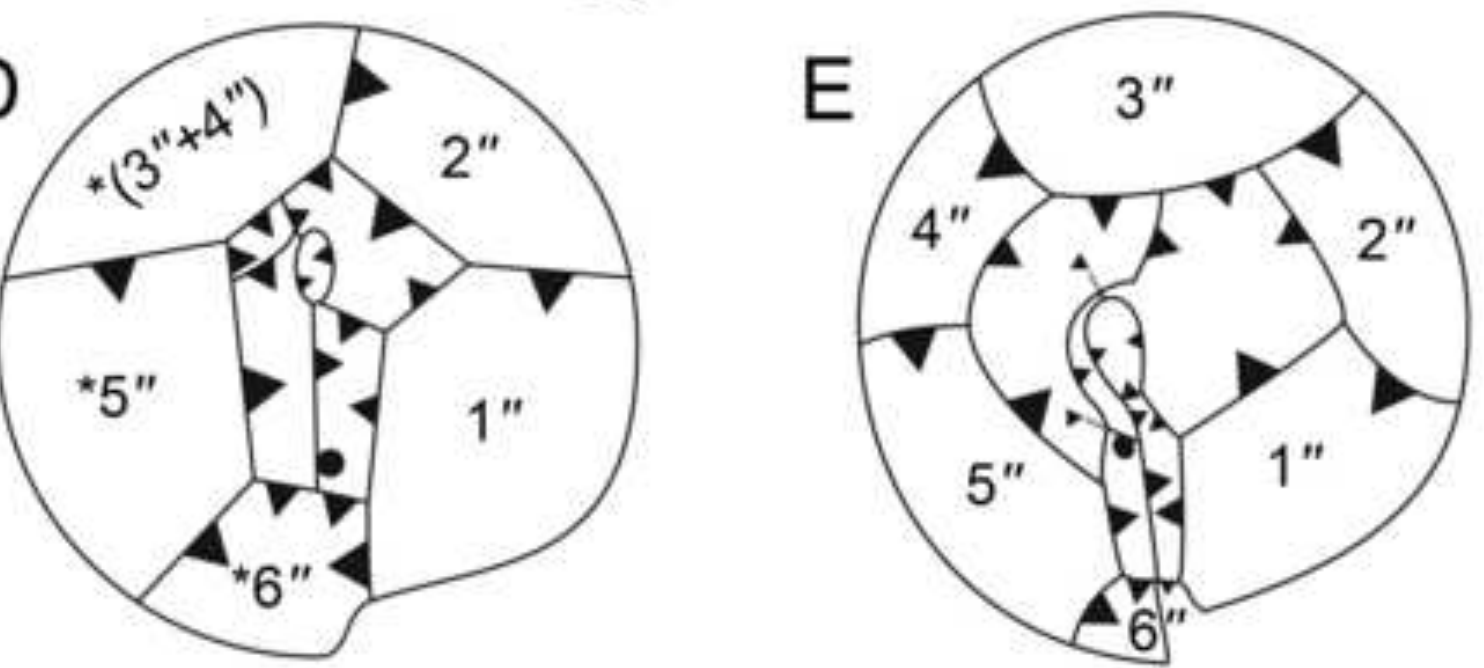


\section{Click here to download high resolution image}

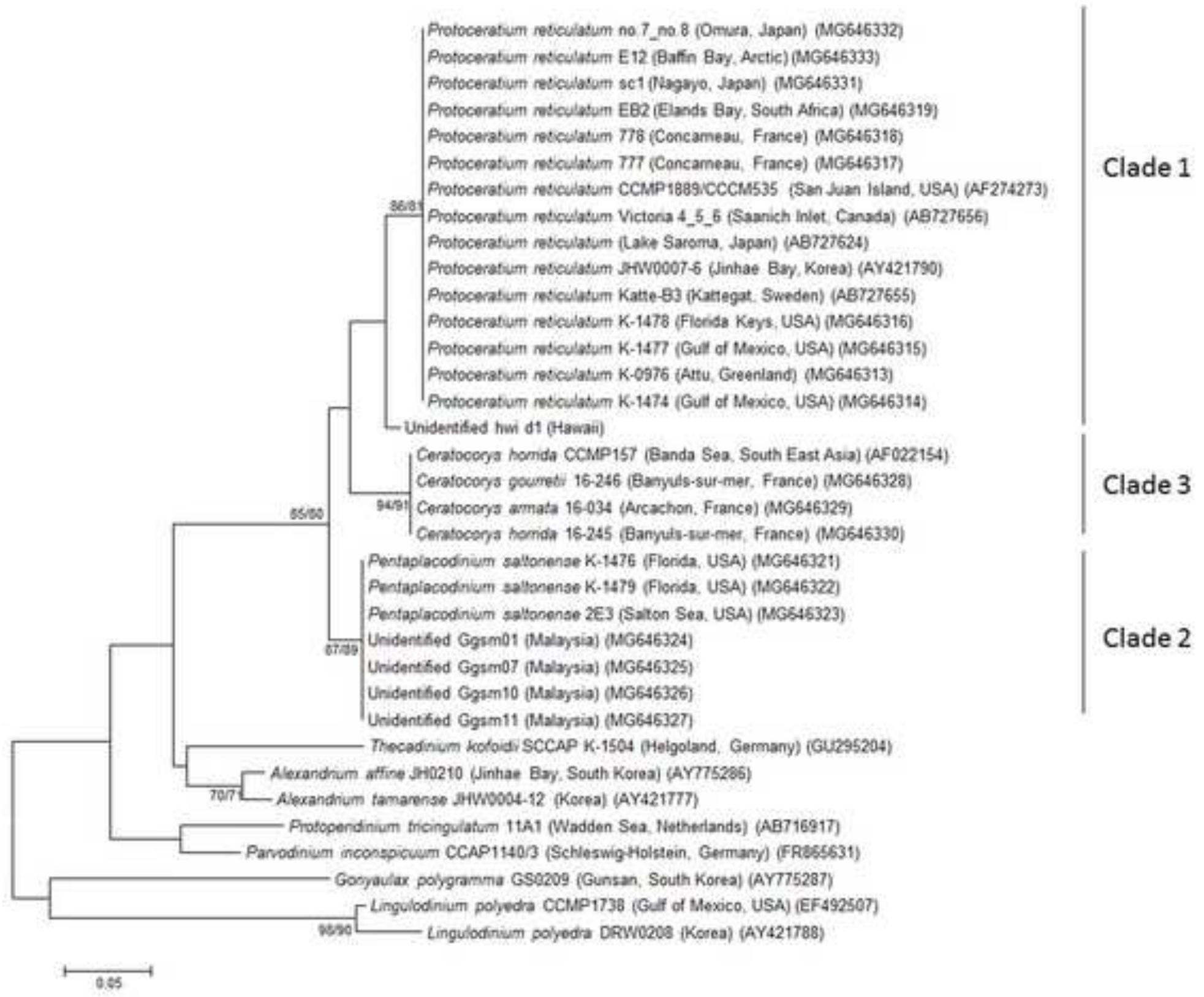

Figure 5 


\section{Click here to download high resolution image}

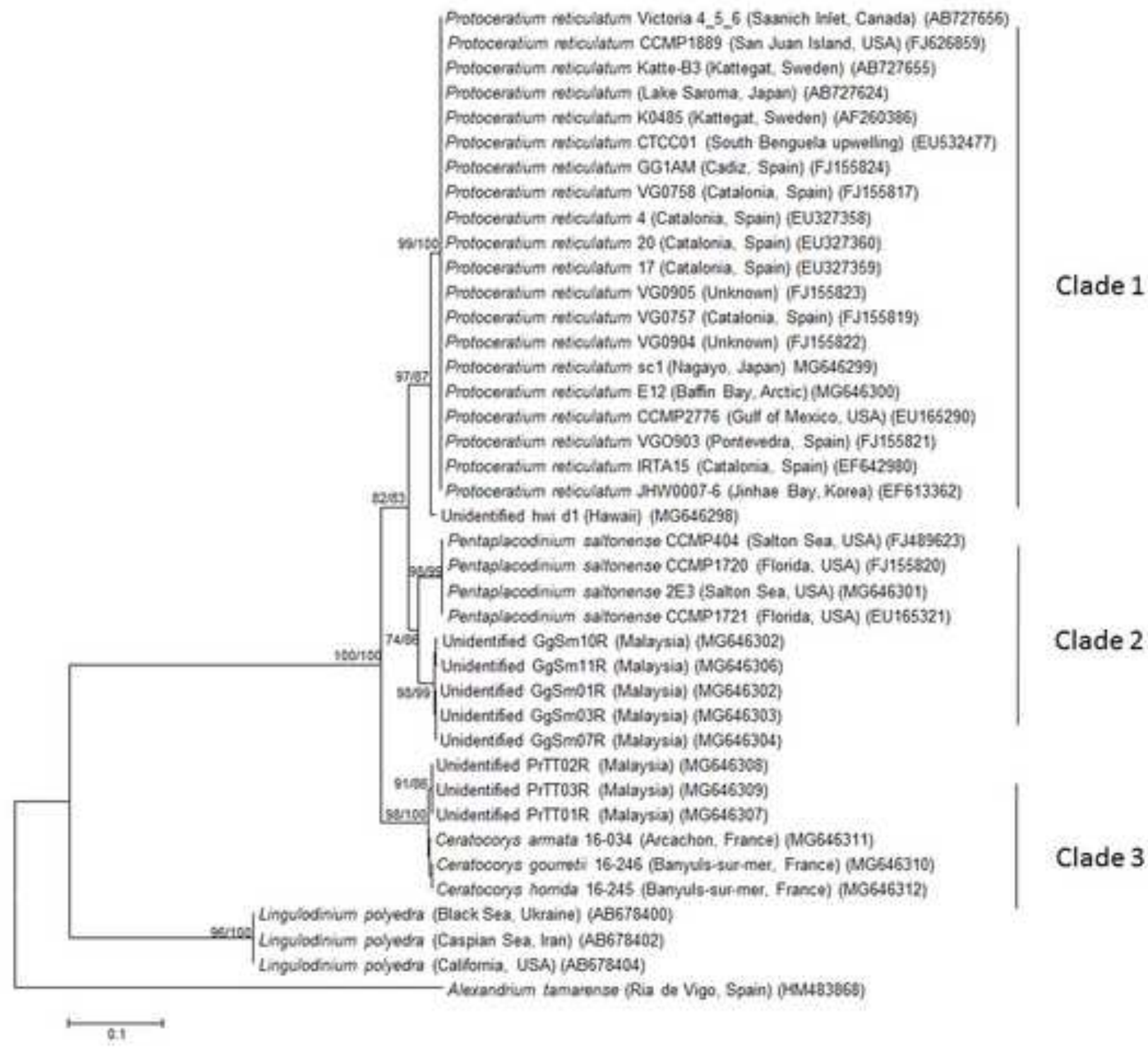

Figure 6 


\section{Click here to download high resolution image}

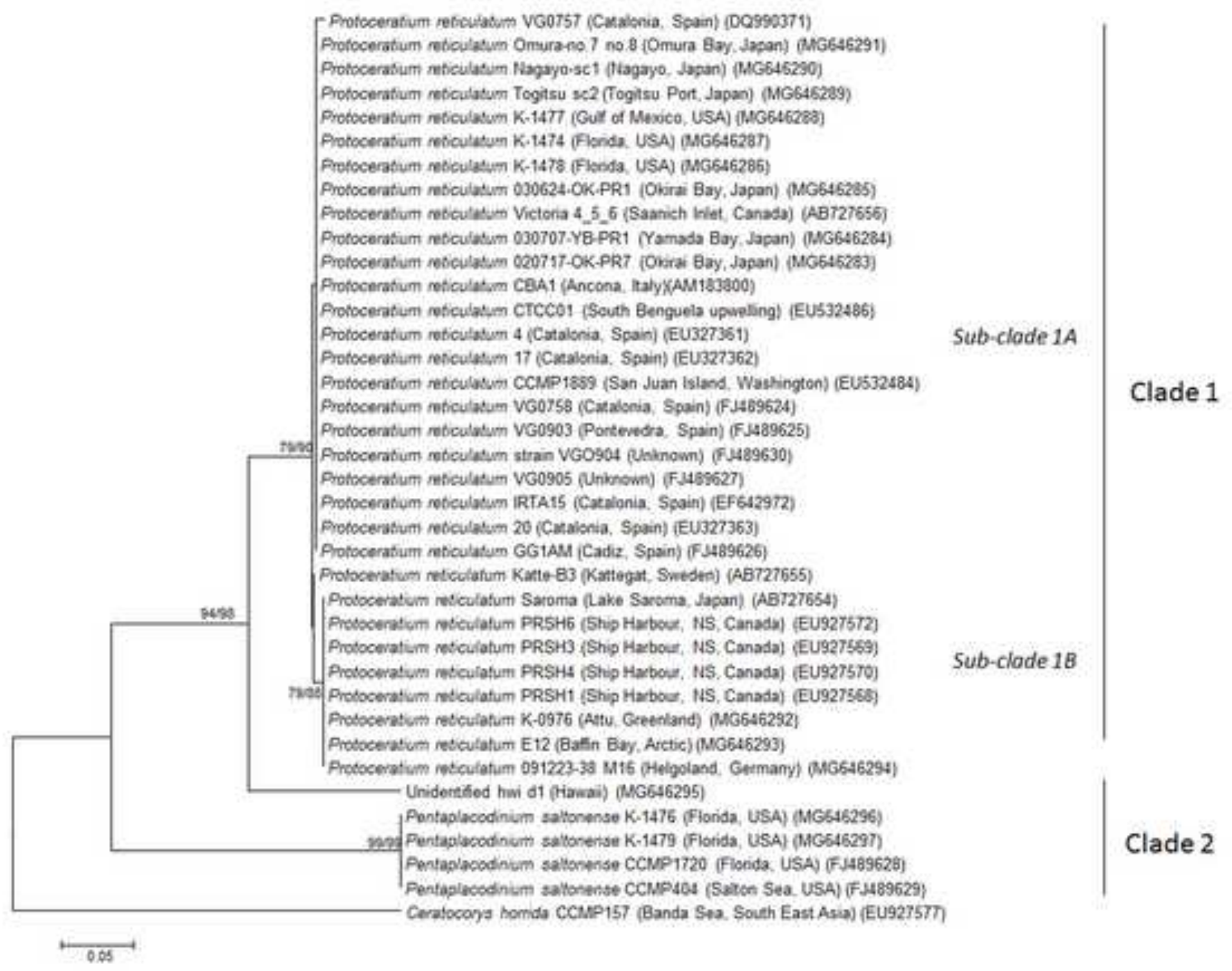

Figure 7

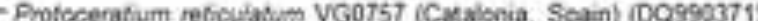

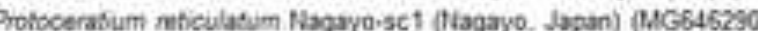

Profoceratium retoulaturn Togitsu sc2 (Togitsu. Port, Japan) (MG646zad)

an) (0AG646284)

ng) (EU532486;

Pmococerafum retculaturi CCUP 1859 (San Juan lslaod Washington) (EU532484)

de 1

460627

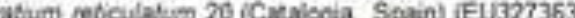

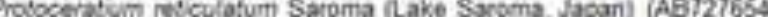

Prodocoratum mbeulatum PRSH4 (Ship Havboiz, NS. Canada) (EU9275TO)

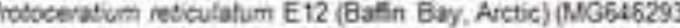
Unidentfod hwi d1 (Hawai) (MG646295)

Pantaplacodinium saltonense K-1476 (Florida, USA) (MGS46296)

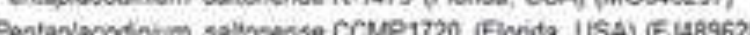

Pentaplacedinim saltontise CCMPSC4 (Saton Sea. USA) (F H89629)

0,05 
Click here to download high resolution image
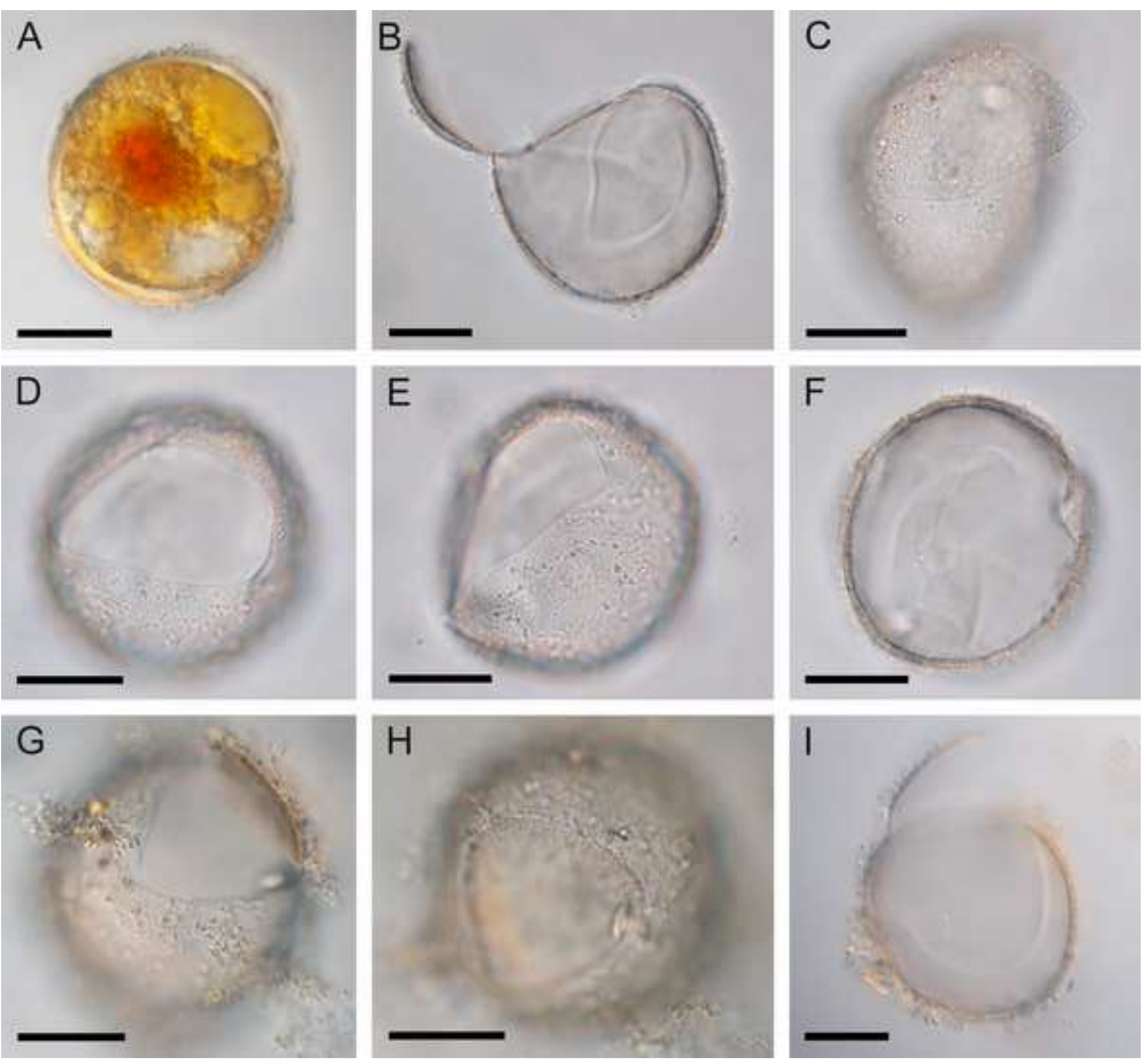
Click here to download high resolution image
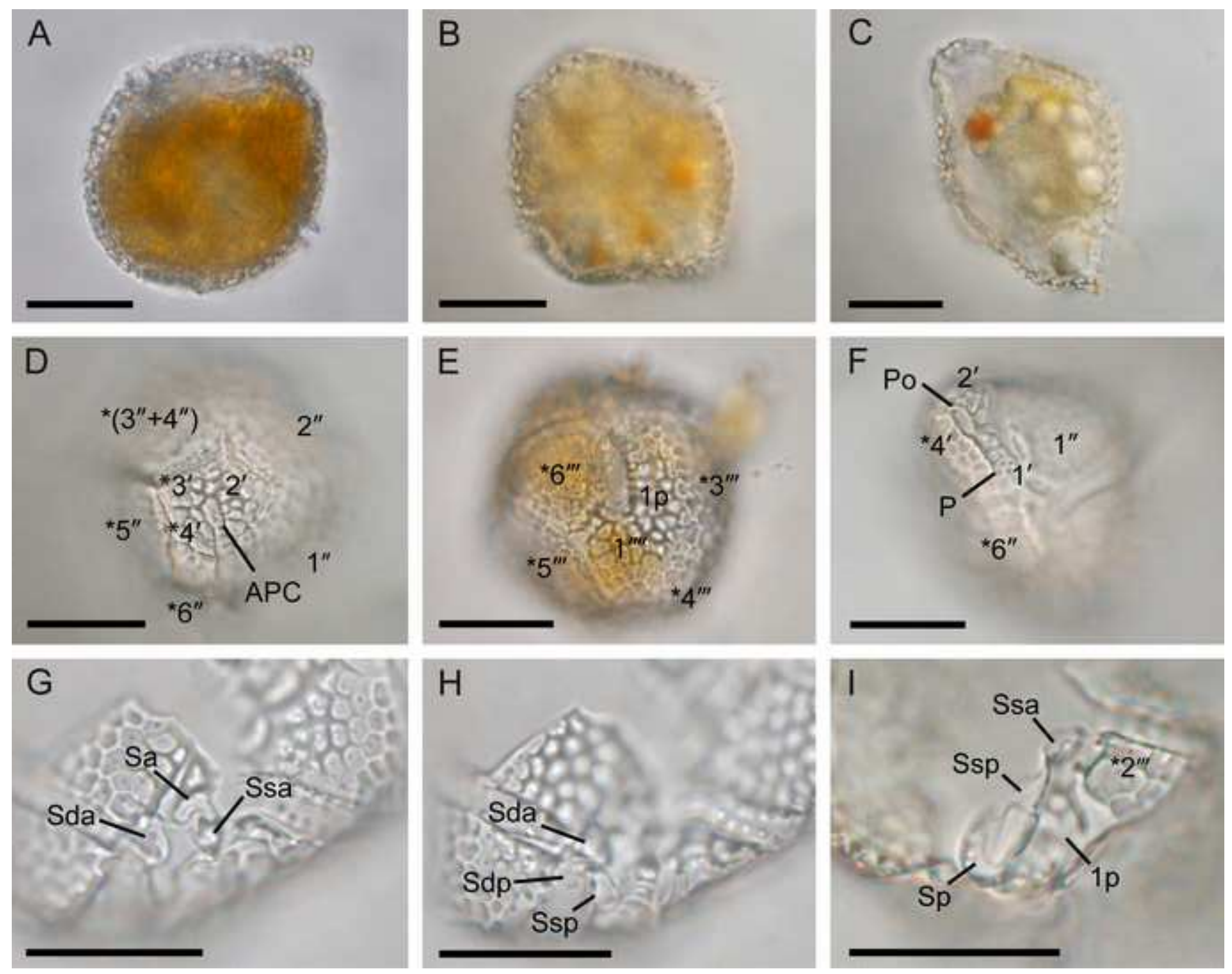


\section{Plate 3}

A

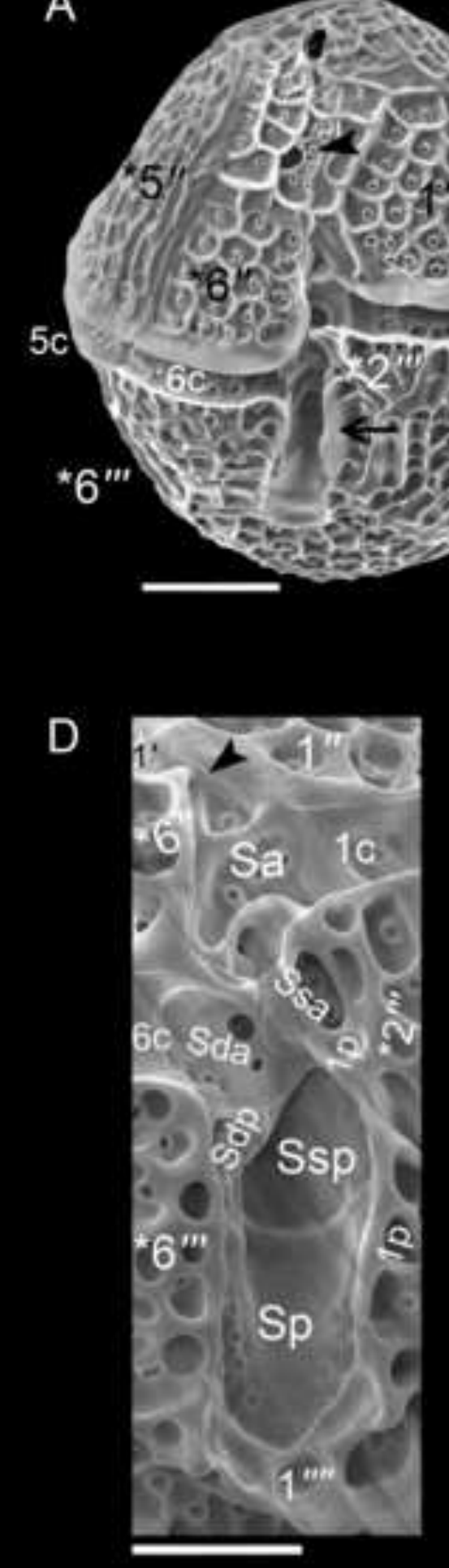

B

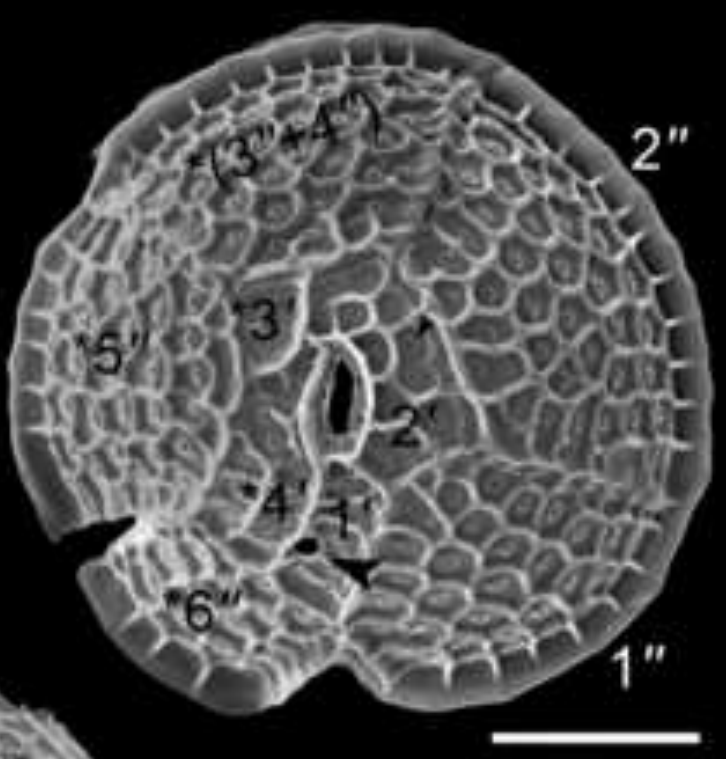

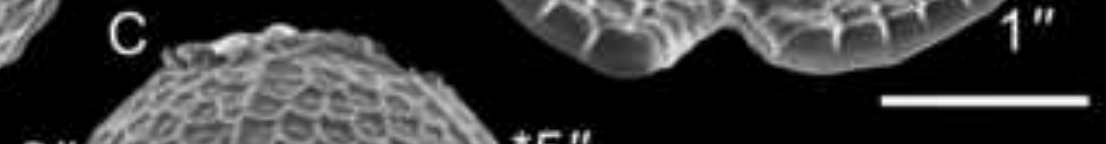

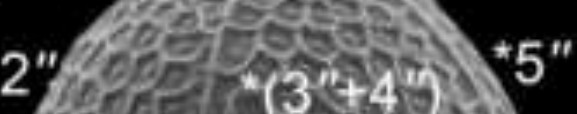

fop b b
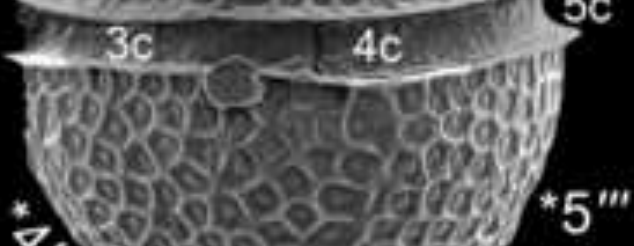

7.

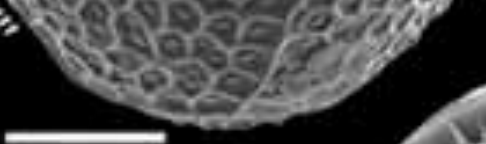

E *2" "6"' 2 a

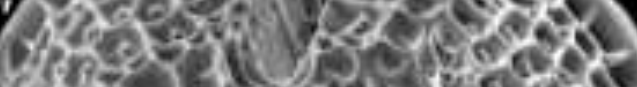

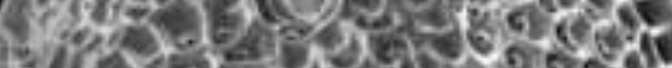

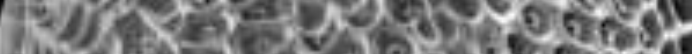

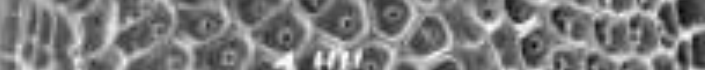

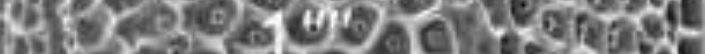

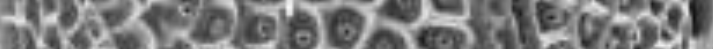

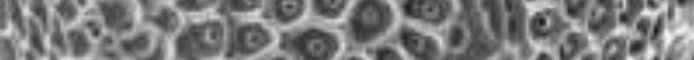

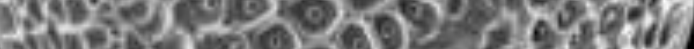

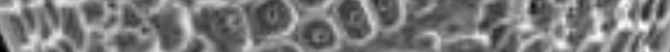

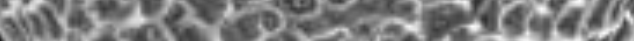
$* 5$

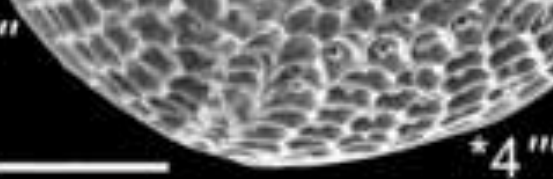


A

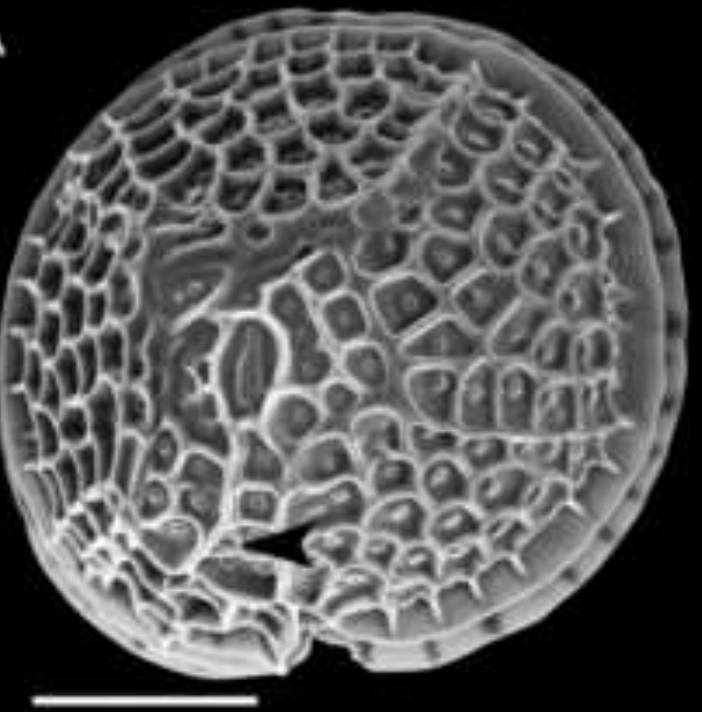

C

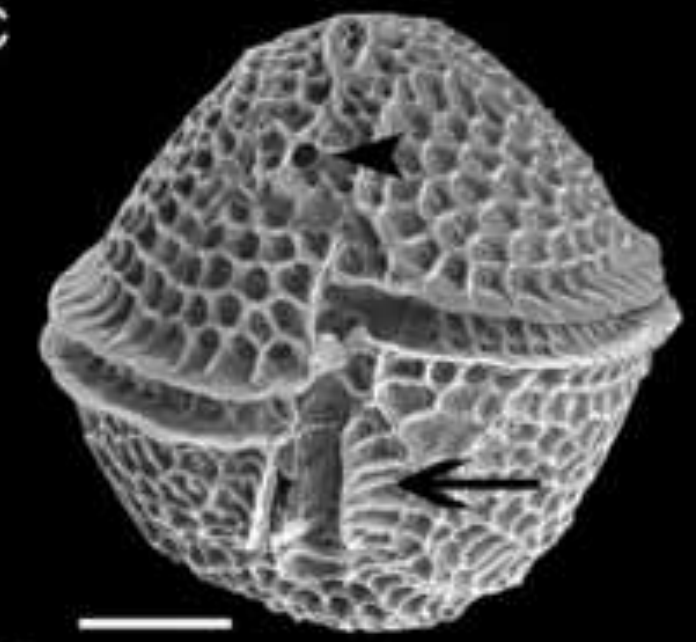

E

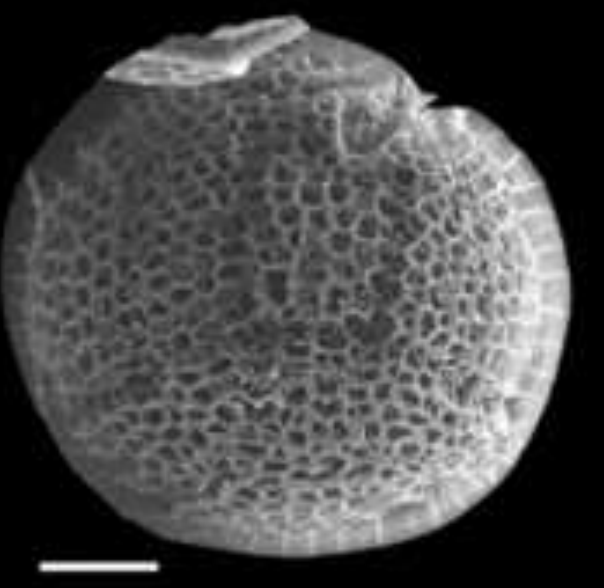

B

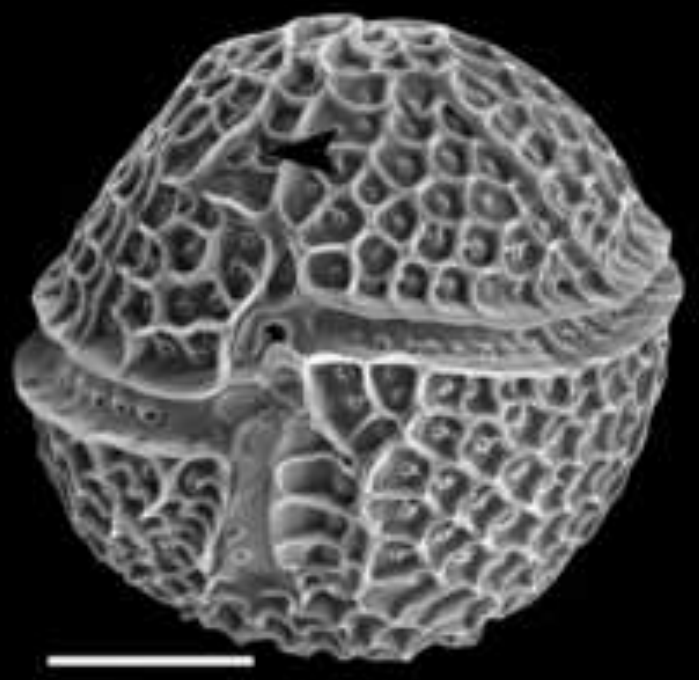

D

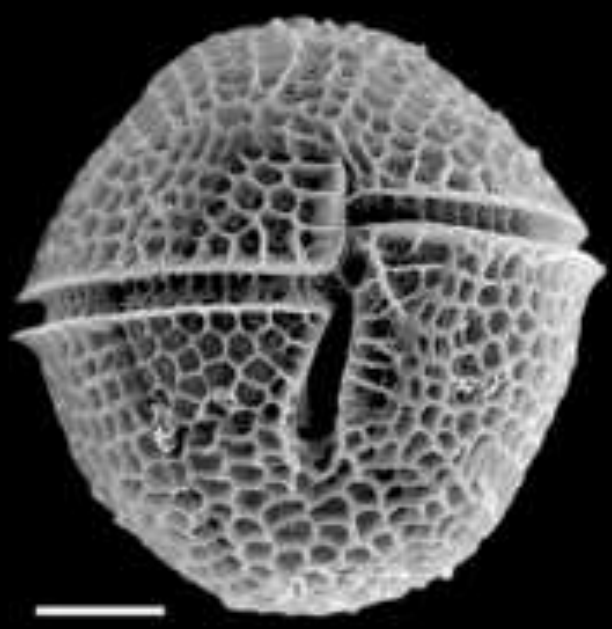

F

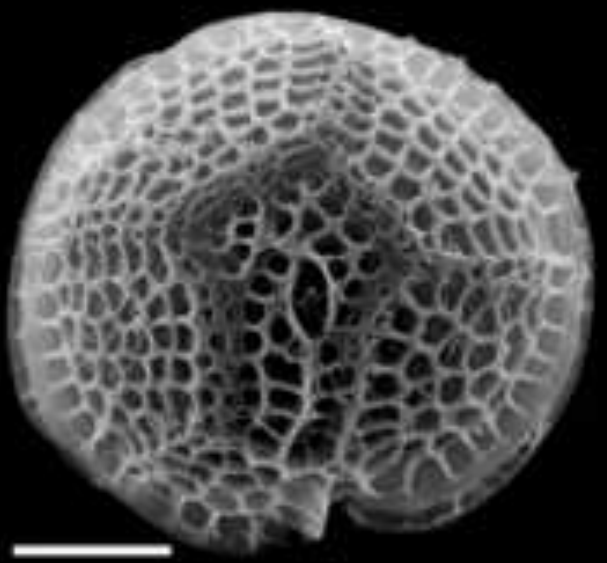


Click here to download high resolution image
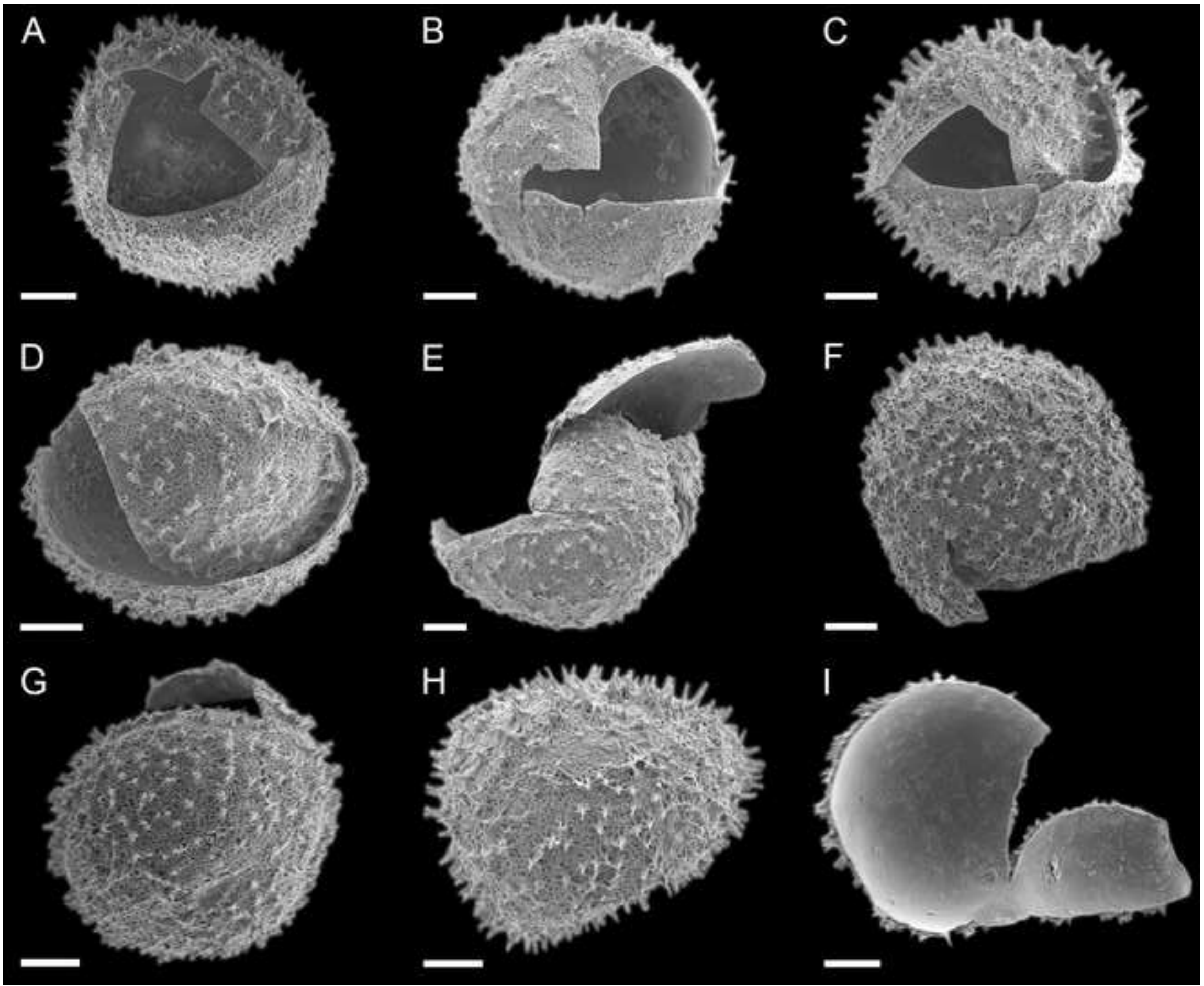
Plate 6
Click here to download high resolution image

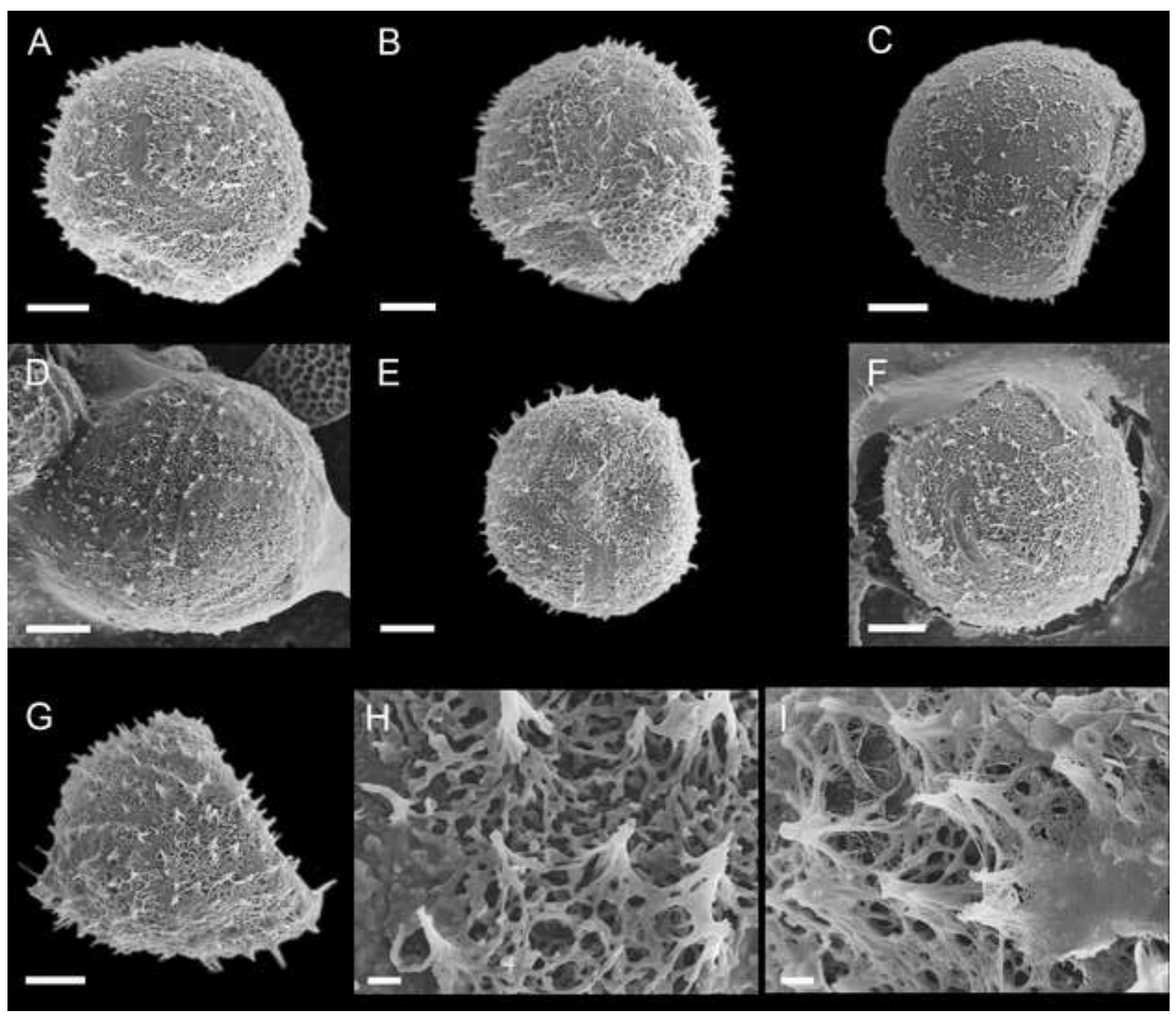


Plate 7

Click here to download high resolution image

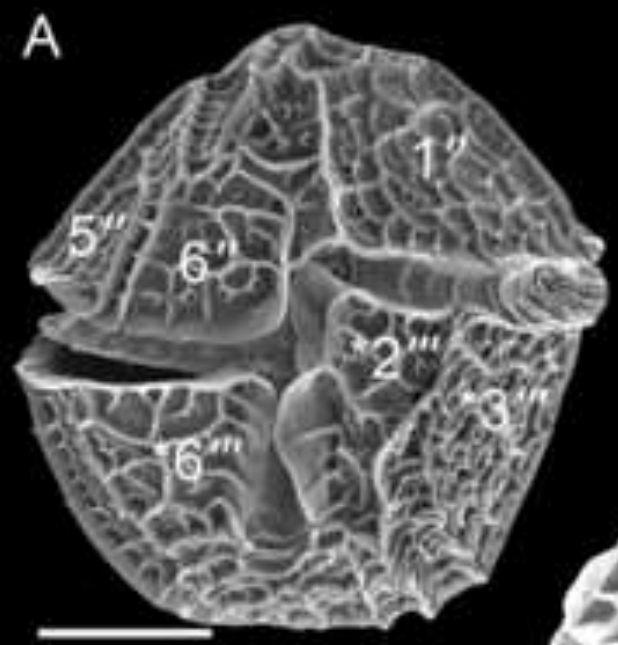

B

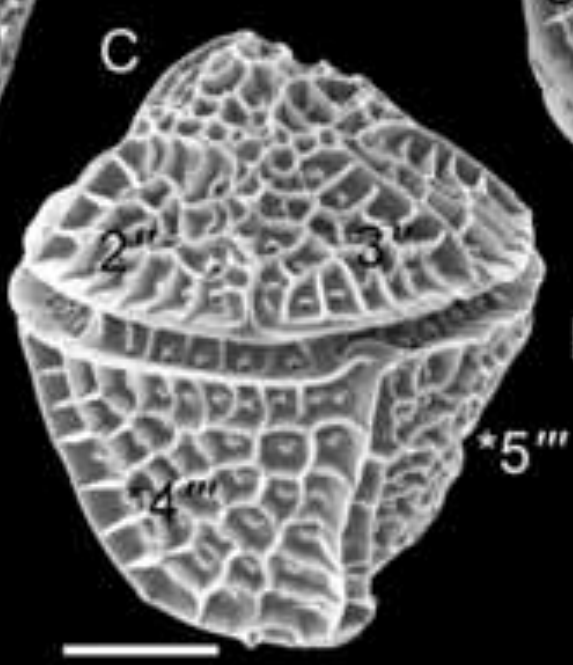

D

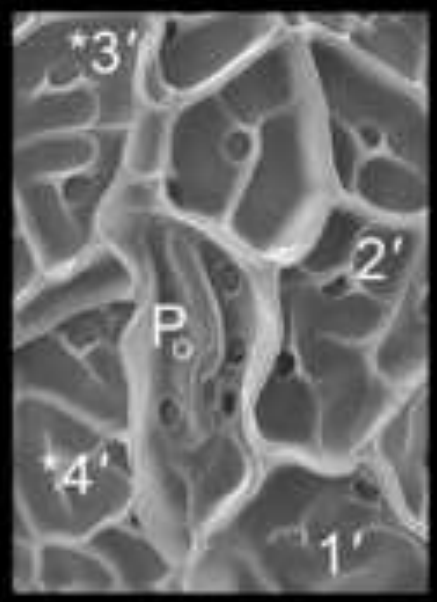

G

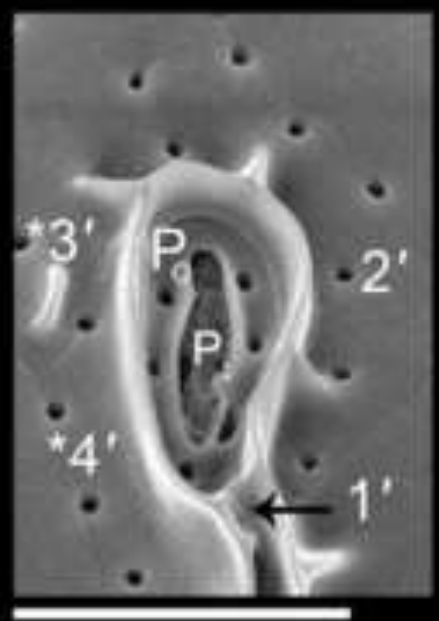

$\mathrm{F}$

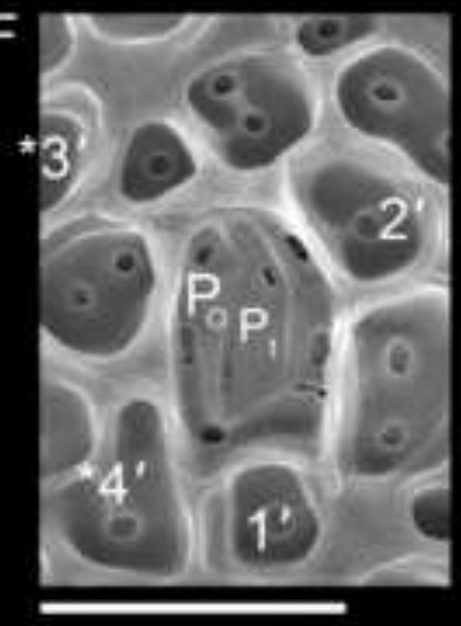

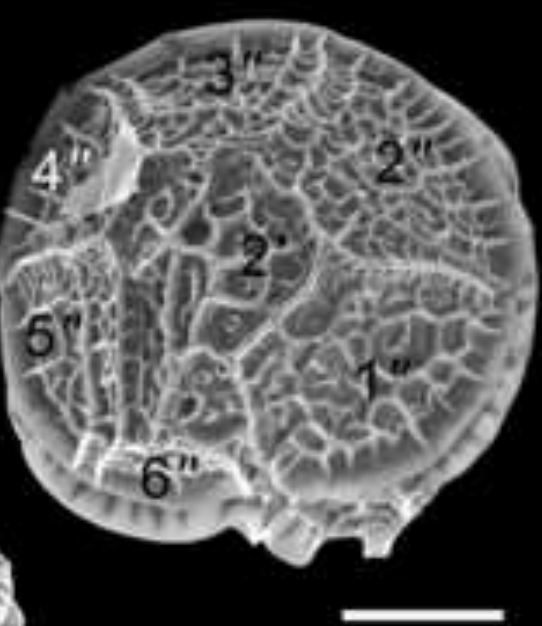

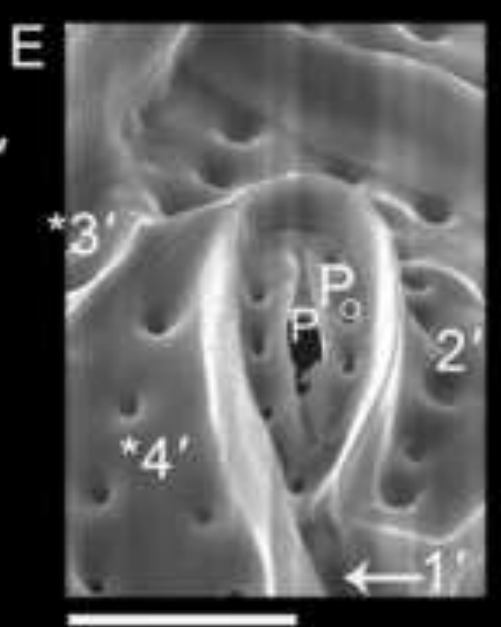

$\mathrm{H}$

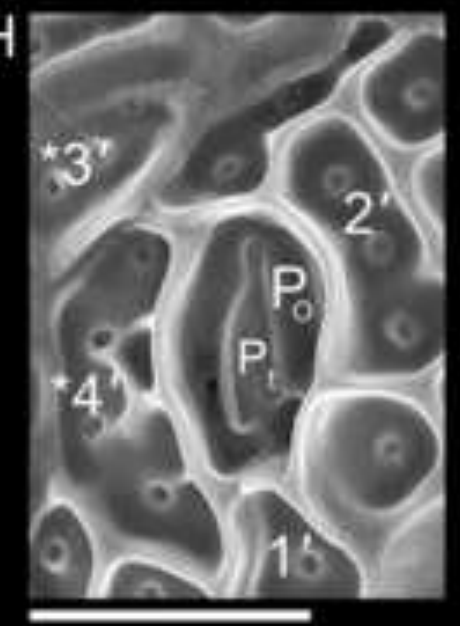


Table 1. Site location of plankton samples investigated, location mark on Figure 1, sampling date, latitude, longitude, sea surface salinity (psu), sea surface temperature $\left({ }^{\circ} \mathrm{C}\right)$, sampling device, used fixative, and name of persons who did

\begin{tabular}{|c|c|c|c|c|c|c|c|c|c|c|}
\hline Sampling site & $\begin{array}{l}\text { Location } \\
\text { mark on } \\
\text { Figure } 1\end{array}$ & Sampling date & $\begin{array}{l}\text { Latitude } \\
\quad\left(^{\circ}\right)\end{array}$ & $\begin{array}{c}\text { Longitude } \\
\left(^{\circ}\right)\end{array}$ & SSS (psu) & SST $\left({ }^{\circ} \mathrm{C}\right)$ & Sampling device & Fixative used & $\begin{array}{l}\text { Species } \\
\text { present }\end{array}$ & Sampled by \\
\hline Salton Sea, St. 1, California, USA & A & 24-Oct-09 & 33,50 & $-115,91$ & $>40.2(62)$ & 23,1 & Plankton net $>20 \mu \mathrm{m}$ & Ethanol 100\% & PS & $\begin{array}{l}\text { KM, VP, MH, } \\
\text { MCCM }\end{array}$ \\
\hline Salton Sea, St. 2, California, USA & A & 24-Oct-09 & 33,50 & $-115,91$ & $>40.2(64)$ & 25,5 & Plankton net $>20 \mu \mathrm{m}$ & Ethanol 100\% & PS & $\begin{array}{l}\text { KM, VP, MH, } \\
\text { MCCM }\end{array}$ \\
\hline Salton Sea, St. 3, California, USA & A & 24-Oct-09 & 33,50 & $-115,92$ & $>40.2(65)$ & 25,5 & Plankton net $>20 \mu \mathrm{m}$ & Ethanol 100\% & PS & $\begin{array}{l}\text { KM, VP, MH, } \\
\text { MCCM }\end{array}$ \\
\hline Salton Sea, St. 4, California, USA & A & 24-Oct-09 & 33,50 & $-115,91$ & $>40.2(56)$ & 30,3 & Plankton net $>20 \mu \mathrm{m}$ & Ethanol 100\% & PS & $\begin{array}{l}\text { KM, VP, MH, } \\
\text { MCCM }\end{array}$ \\
\hline Salton Sea, St. 5, California, USA & A & 24-Oct-09 & 33,50 & $-115,91$ & $>40.2(65)$ & $\sim 30$ & Plankton net $>20 \mu \mathrm{m}$ & Ethanol 100\% & PS & $\begin{array}{l}\text { KM, VP, MH, } \\
\text { MCCM }\end{array}$ \\
\hline Off Yucatan, St. 4, Gulf of Mexico, Mexico & B & 19-May-09 & 21,39 & $-88,08$ & 31,0 & 24,1 & Plankton tow $>20 \mu \mathrm{m}$ & Formaldehyde & PS & YO \\
\hline Off Yucatan, Gulf of Mexico, Mexico & B & 19-May-09 & 21,40 & $-88,84$ & 31,0 & 24,1 & Plankton tow $>20 \mu \mathrm{m}$ & Formaldehyde & PS & YO \\
\hline Indian River Lagoon, St. TR, Florida, USA & $\mathrm{C}$ & 28-May-08 & 27,50 & $-80,34$ & 37,4 & 29,5 & Plankton tow $>20 \mu \mathrm{m}$ & Formalin $2 \%$ & PS & $\mathrm{PH}$ \\
\hline Off Qatar, Persian Gulf & D & Sept. 1991 & 25,29 & 51,54 & $38-43$ & $20-35$ & Plankton net & Formalin $5 \%$ & PS & $\mathrm{AA}$ \\
\hline North Sea, Helgoland, Germany & E & 3-Jun-02 & 54,19 & 7,90 & 32,0 & 12,5 & Plankton net $>20 \mu \mathrm{m}$ & Lugol & PR & МHO \\
\hline Kattegat, St. Central, Denmark & $\mathrm{F}$ & NA & 56,92 & 11,28 & NA & NA & Plankton net & Lugol \& Formalin & PR & $\mathrm{JL}$ \\
\hline Kattegat, St. 431, Denmark & $\mathrm{F}$ & 22-Jun-05 & 55,77 & 12,75 & NA & $\mathrm{NA}$ & Plankton net & Lugol & PR & $\mathrm{JL}$ \\
\hline Kattegat, St. 925, Denmark & $\mathrm{F}$ & 17-Aug-00 & 56,08 & 11,02 & NA & NA & Plankton net & Lugol & PR & $\mathrm{JL}$ \\
\hline Baltic Sea, St. F64, Finland & G & 20-Aug-10 & 60,18 & 19,13 & 5,7 & 17,6 & Plankton net & Lugol & PR & $\mathrm{AK}, \mathrm{MHU}$ \\
\hline Gulf of Bothnia, Baltic Sea, St. US5B, Finland & $\mathrm{H}$ & 20-Aug-10 & 62,58 & 19,98 & 5,1 & 16,0 & Plankton net & Lugol & PR & $\mathrm{AK}, \mathrm{MHU}$ \\
\hline Western Greenland, St. 516, Denmark & I & 30-Jul-12 & 69,20 & $-54,10$ & 33,2 & 6,9 & Water Bottle-CTD & Formaldehyde & $\mathrm{PR}$ & UT \\
\hline Baffin Bay, St. 2008-029-0039/9/0039A, Canada & $\mathrm{J}$ & 6-Sep-08 & 76,57 & $-73,96$ & 31,0 & 2,2 & Plankton net $>20 \mu \mathrm{m}$ & Formaldehyde & $\mathrm{PR}$ & $\mathrm{AR}$ \\
\hline Baffin Bay, St. 2008-029-027A, Canada & $\mathrm{J}$ & 5-Sep-08 & 77,29 & $-74,34$ & 30,8 & 2,2 & Plankton net $>20 \mu \mathrm{m}$ & Formaldehyde & PR & $\mathrm{AR}$ \\
\hline Baffin Bay, St. 2008-029-0043A, Canada & K & 7-Sep-08 & 75,58 & $-78,63$ & 31,0 & 2,0 & Plankton net $>20 \mu \mathrm{m}$ & Formaldehyde & PR & $\mathrm{AR}$ \\
\hline Baffin Bay, St. 2008-029-0035A, Canada & $\mathrm{J}$ & 6-Sep-08 & 76,33 & $-71,43$ & 31,0 & 4,5 & Plankton net $>20 \mu \mathrm{m}$ & Formaldehyde & $\mathrm{PR}$ & $\mathrm{AR}$ \\
\hline Off Puerto Aguirre, Chile & $\mathrm{L}$ & 21-May-06 & $-44,99$ & $-73,53$ & 28,8 & 10,0 & Plankton net $>26 \mu \mathrm{m}$ & Formaldehyde & $\mathrm{PR}$ & $\mathrm{xv}$ \\
\hline Elands Bay, South Africa & M & 16-Mar-13 & $-32,31$ & 18,32 & NA & NA & Plankton net & Formaldehyde & PR & MP \\
\hline Off Cape Town, South Africa & M & NA & $-33,89$ & 18,42 & NA & NA & Plankton net & $\begin{array}{l}\text { Lugol + formalin } \\
\text { Glutaraldehyde }\end{array}$ & PR & $\mathrm{JL}$ \\
\hline Mutsu Bay, Aomori, Japan & $\mathrm{N}$ & 5-Apr-10 & 40,92 & 141,12 & 32,7 & 5,9 & Plankton net $>20 \mu \mathrm{m}$ & & PR & KK \\
\hline Okkirai Bay, Iwate, Japan & $\mathrm{O}$ & 16-Jul-03 & 39,08 & 141,85 & 32,6 & 15,8 & Plankton net $>20 \mu \mathrm{m}$ & $\begin{array}{l}\text { Glutaraldehyde } \\
5 \% \\
\text { Glutaraldehyde }\end{array}$ & PR & KK \\
\hline Okkirai Bay, Iwate, Japan & o & 28-Aug-03 & 39,08 & 141,85 & 32,3 & 20,0 & Plankton net $>20 \mu \mathrm{m}$ & $\begin{array}{l}5 \% \\
\text { Glutaraldehyde }\end{array}$ & PR & KK \\
\hline Okkirai Bay, Iwate, Japan & $\mathrm{o}$ & 23-Jun-04 & 39,08 & 141,85 & 32,7 & 16,0 & Plankton net $>20 \mu \mathrm{m}$ & $5 \%$ & PR & KK \\
\hline Okkirai Bay, Iwate, Japan & o & 12-Aug-04 & 39,08 & 141,85 & 33,5 & 23,0 & Plankton net $>20 \mu \mathrm{m}$ & $5 \%$ & PR & KK \\
\hline Omura Bay, Nagayo-ura, Japan & $P$ & 9-May-11 & 32,85 & 129,87 & 32,7 & 20,2 & Plankton net $>20 \mu \mathrm{m}$ & Formalin & $\mathrm{PR}$ & KMA \\
\hline Omura Bay, Inoura, Japan & $\mathrm{P}$ & 12-May-11 & 33,05 & 129,74 & 25,6 & 18,5 & Plankton net $>20 \mu \mathrm{m}$ & Formalin & $\mathrm{PR}$ & KMA \\
\hline Omura Bay, Togitsu Port, Japan & $P$ & 23-May-11 & 32,85 & 129,87 & 32,6 & 19,5 & Plankton net $>20 \mu \mathrm{m}$ & Formalin & PR & KMA \\
\hline Kagoshima Bay, St. 1, Japan & $\mathrm{P}$ & 20-Jun-11 & 31,55 & 130,57 & 23,8 & 22,9 & Plankton net $>20 \mu \mathrm{m}$ & Formalin & PR & KMA \\
\hline Saroma Lake (Lagoon), St. 1, Japan & $\mathrm{Q}$ & 22-Jul-11 & 44,12 & 143,82 & 32,2 & 17,1 & Plankton net & Ethanol & PR & KM \\
\hline
\end{tabular}


Abbreviations: $\mathrm{NA}=$ Not available, $\mathrm{PS}=$ Pentaplacodinium saltonense, $\mathrm{PR}=$ Protoceratium reticulatum, $\mathrm{AK}=\mathrm{Anke}$ Kremp, $\mathrm{AR}=$ André $\mathrm{Rochon}, \mathrm{AA}=\mathrm{Abdulrahman}$ Al-Muftah, $M \mathrm{CCM}=\mathrm{Consuelo}$ Carbonell-Moore, $\mathrm{JL}=\mathrm{Jacob}$ Larsen, $\mathrm{KK}=$ Kazuhiko Koike, KM = Kenneth Neil Mertens, KMA = Kazumi Matsuoka, MH= Martin J. Head, MHO = Mona Hoppenrath, MHU=Maija Huttunen, MP = Maya Pfaff, PH = Paul Hargreaves, UT = Urban Tillmann, VP = Vera Pospelova, XV = Ximena Vivanco, YO = Yuri B. Okolodkow 
Suppl. Table 1. Culture strains and cells or cyst picked for SEM and/or phylogenetic analysis

\begin{tabular}{|c|c|c|c|c|c|c|c|c|c|c|}
\hline CODI (Strain ID) & $\begin{array}{l}\text { Identified here by its } \\
\text { morphology as }\end{array}$ & Geographic Origin & $\begin{array}{c}\text { Latitude } \\
\left({ }^{\circ} \mathbf{N}\right)\end{array}$ & $\begin{array}{c}\text { Longitude } \\
\left({ }^{\circ} \mathbf{E}\right)\end{array}$ & Isolation date & Isolated by & LSU (28S) Genbank & ITS Genbank & SSU (18S) Genbank & Sequenced in this study by \\
\hline CCMP404 = ALO011 & P. saltonense & $\begin{array}{l}\text { Salton Sea (California) } \\
\text { (a) }\end{array}$ & $\begin{array}{l}33.375 \\
33^{\circ}\end{array}$ & -116.0 & 1966 & Dodson, A. & EU532476 & $\begin{array}{l}\text { FJ489629 } \\
\text { Not }\end{array}$ & FJ489629*** & \\
\hline Salton Sea $2 \mathrm{E} 3 *$ & P. saltonense & Salton Sea (California) & $30.122^{\prime}$ & $-115^{\circ} 54.879^{\prime}$ & 19/11/2013 & Mertens, $\mathrm{K}$. & MG646301 & sequenced & MG646323 & Aika Yamaguchi \\
\hline ALO013 & P. saltonense & Biscayne Bay (Florida) & 25.8 & -80.3333 & $15 / 02 / 1995$ & Hargraves, $\mathrm{P}$. & FJ 155820 & FJ489628 & FJ489628**** & \\
\hline $\begin{array}{l}\text { CCMP1721 = K-1480 = } \\
\text { ALO012 }\end{array}$ & P. saltonense & Biscayne Bay (Florida) & 25.8 & -80.3333 & 01/06/1994 & Hargraves, $\mathrm{P}$. & EU165321 & $\begin{array}{l}\text { Not } \\
\text { sequenced }\end{array}$ & Not sequenced & \\
\hline CCMP3241 = K-1479 & P. saltonense & Indian River Lagoon (Florida) & 27.83 & -80.45 & $11 / 06 / 2008$ & Hargraves, $P$. & Not sequenced & MG646297 & MG646322 & $\begin{array}{l}\text { Andrea Highfield / Declan } \\
\text { Schroeder }\end{array}$ \\
\hline ССMP $3243=\mathrm{K}-1476$ & P. saltonense & Indian River Lagoon (Florida) & 27.83 & -80.45 & $05 / 06 / 2008$ & Hargraves, P. & Not sequenced & MG646296 & MG646321 & $\begin{array}{c}\text { Andrea Highfield / Declan } \\
\text { Schroeder }\end{array}$ \\
\hline CCMP3031 = K-1474 & P. reticulatum & Off coast Florida, Gulf of Mexico & 25.0167 & -81.4003 & NA & NA & Not sequenced & MG646287 & MG646314 & $\begin{array}{l}\text { Andrea Highfield / Declan } \\
\text { Schroeder }\end{array}$ \\
\hline Victoria-no.4_5_6* & P. reticulatum & Brentwood Bay, Saanich Inlet & 48.57 & 123.47 & Oct. 2011 & Mertens, $K$. & AB727656 & AB727656 & AB727656 & \\
\hline $\begin{array}{l}\text { CCMP1889 }=\text { K-0634 = } \\
\text { CCCM535 }\end{array}$ & NA & $\begin{array}{l}\text { Friday Harbor, San Juan Island, } \\
\text { Washington USA }\end{array}$ & 48.544 & -123.01 & 1983 & Taylor, F.J.R. & EU532475 & EU532484 & FJ $626858^{* * * *}$ & \\
\hline CCMP2776 = K-1477 & P. reticulatum & Gulf of Mexico, U.S.A. & 25,0167 & $-81,4003$ & NA & Sinigalliano, $\mathrm{C}$. & EU165290 & MG646288 & MG646315 & $\begin{array}{c}\text { Andrea Highfield / Declan } \\
\text { Schroeder }\end{array}$ \\
\hline $\mathrm{CCMP} 3113=\mathrm{K}-1478$ & P. reticulatum & Marquesa Keys, Florida Keys & -24.58 & -82.1 & NA & NA & Not sequenced & MG646286 & MG646316 & $\begin{array}{l}\text { Andrea Highfield / Declan } \\
\text { Schroeder }\end{array}$ \\
\hline VGO757 & $\mathrm{NA}$ & Ebro Delta (Catalonia, Spain) & NA & $\mathrm{NA}$ & NA & Fernandez-Tejedor, M. & FJ155819 & DQ990371 & DQ990371*** & \\
\hline VGO758 & P. reticulatum $* *$ & Alfacs Bay, Ebro Delta (Catalonia Spain) & $\mathrm{NA}$ & NA & $\mathrm{NA}$ & Fernandez-Tejedor. M. & FJ155817 & FJ489624 & FJ489624*** & \\
\hline $\mathrm{VGO} 003=\mathrm{ALO014}$ & P. reticulatum** & Ría de Ponteverde (Bueu) & NA & NA & NA & Fernandez-Tejedor, M. & FJ155821 & FJ 489625 & FJ489625*** & \\
\hline VGO904 & NA & NA & NA & NA & NA & Fernandez-Tejedor, $\mathrm{M}$. & FJ155822 & FJ489630 & FJ489630*** & \\
\hline VGO905 & NA & NA & NA & NA & NA & Fernandez-Tejedor, M. & FJ155823 & FJ489627 & FJ489627**** & \\
\hline IRTA015 & P. reticulatum & Ebro Delta (Catalonia Spain) & NA & NA & NA & Fernandez-Tejedor, M. & EF642980 & EF642972 & EF642972*** & \\
\hline 20 & NA & Catalan Coast & NA & NA & NA & Fernandez-Tejedor, M. & Not sequenced & EU327363 & EU327363**** & \\
\hline GG1AM & NA & La Atunara (Cádiz, Spain) & NA & NA & NA & Fernandez-Tejedor, M. & FJ155824 & FJ489626 & FJ $489626 * * *$ & \\
\hline 17 & NA & Catalan Coast & NA & NA & NA & Fernandez-Tejedor, M. & Not sequenced & EU327362 & EU327362**** & \\
\hline 4 & NA & Catalan Coast & NA & NA & NA & Fernandez-Tejedor, M. & Not sequenced & EU327361 & EU327361**** & \\
\hline Katte-B3 * & P. reticulatum (cyst-based) & Kattegat, Swedish coast & 57.5 & 11.8 & Nov. 2011 & Mertens, $\mathrm{K}$. & $\mathrm{AB} 727655$ & $\mathrm{AB} 727655$ & AB727655 & \\
\hline $\begin{array}{l}\text { 091223-38_M16_Protocer3- } \\
\text { ITS1 }\end{array}$ & P. reticulatum & Helgoland, Germany & 54,19 & 7,9 & avr-03 & Hoppenrath, M. & Not sequenced & MG646294 & Not sequenced & Karin Röder \\
\hline Lake Saroma * & P. reticulatum (cyst-based) & Lake Saroma, Japan & 44.12 & 143.87 & Aug. 2011 & Mertens, $\mathrm{K}$. & AB727654 & AB727654 & AB727654 & \\
\hline K-0976 & P. reticulatum & Attu, Greenland & 67.924068 & -53.649824 & 21.08 .2005 & Moestrup, Ø. & Not sequenced & MG646292 & MG646313 & $\begin{array}{l}\text { Andrea Highfield / Declan } \\
\text { Schroeder }\end{array}$ \\
\hline & P. reticulatum & Station 323, Northern Baffin Bay & 74.12 & 79.45 & 02-mai-11 & Mertens, $\mathrm{K}$. & MG646300 & MG646293 & MG646333 & Yoshihito Takano \\
\hline K-0485 & P. reticulatum & Southern Kattegat, Bouy St. & 56.20 & 12.04 & 03-avr-89 & Hansen, G. & AF260386 & sequenced & Not sequenced & \\
\hline PRSH6 (NRC Halifax) & P. reticulatum & Ship harbour, NS, Canada & NA & NA & NA & Ferrell, J. F. & Not sequenced & EU927572 & EU927572**** & \\
\hline PRSH3 (NRC Halifax) & P. reticulatum & Ship harbour, NS, Canada & NA & NA & NA & Ferrell, J. F. & Not sequenced & EU927569 & EU927569*** & \\
\hline PRSH4 (NRC Halifax) & P. reticulatum & Ship harbour, NS, Canada & NA & NA & NA & Ferrell, J. F. & Not sequenced & EU927570 & EU927570**** & \\
\hline PRSH1 (NRC Halifax) & P. reticulatum & Ship harbour, NS, Canada & NA & NA & NA & Ferrell, J. F. & Not sequenced & EU927568 & EU927568**** & \\
\hline СТСС 01 & P. reticulatum & Southern Benguela upwelling region & NA & NA & NA & NA & EU532477 & EU532486 & EU532486**** & \\
\hline Elands Bay 2013 (EB2) * & P. reticulatum & Elands Bay, South Africa & $32^{\circ} 18.618^{\prime}$ & $18^{\circ} 19.267$ & 16 March 2013 & Carbonell-Moore, C. & Not sequenced & $\begin{array}{c}\text { Not } \\
\text { sequenced }\end{array}$ & MG646319 & $\begin{array}{l}\text { Andrea Highfield / Declan } \\
\text { Schroeder }\end{array}$ \\
\hline
\end{tabular}




\begin{tabular}{|c|c|c|c|c|c|c|c|c|c|c|}
\hline $\begin{array}{l}\text { JHW0007-6 } \\
\text { CBA-1 } \\
\text { 020717-OK-PR7 } \\
\text { 030707-YB-PR1 } \\
\text { 030624-OK-PR1 } \\
\text { Omura-no.7_no.8* } \\
\text { Nagayo-sc1 * } \\
\text { Togitsu-sc2 * } \\
777 \\
778 \\
\end{array}$ & $\begin{array}{l}\text { NA } \\
\text { NA } \\
\text { P. reticulatum } \\
\text { P. reticulatum } \\
\text { P. reticulatum } \\
\text { P. reticulatum } \\
\text { P. reticulatum } \\
\text { P. reticulatum } \\
\text { P. reticulatum } \\
\text { P. reticulatum } \\
\end{array}$ & $\begin{array}{l}\text { Jinhae Bay, Korea } \\
\text { Adriatic Sea, Ancona, Italy } \\
\text { Okkirai Bay, Iwate, Japan } \\
\text { Yamada Bay, Iwate, Japan } \\
\text { Okkirai Bay, Iwate, Japan } \\
\text { Omura Bay, Japan } \\
\text { Nagayo, Japan } \\
\text { Togitsu Port, Japan } \\
\text { Concarneau large, France } \\
\text { Concarneau large, France } \\
\end{array}$ & \begin{tabular}{c|} 
NA \\
NA \\
39.08 \\
39.46 \\
39.08 \\
32.85 \\
32.85 \\
32.85 \\
47.83 \\
47.83 \\
\end{tabular} & $\begin{array}{c}\mathrm{NA} \\
\mathrm{NA} \\
141.85 \\
141.97 \\
141.85 \\
129.87 \\
129.87 \\
129.87 \\
-3.95 \\
-3.95 \\
\end{array}$ & $\begin{array}{c}\text { juil-00 } \\
\text { NA } \\
\text { 17-Jul-02 } \\
\text { 7-Jul-03 } \\
\text { 24-Jun-03 } \\
\text { 2 may 2011 } \\
\text { 24 May 2011 } \\
\text { 23 May 2011 } \\
\text { 16 July 2008 } \\
\text { 16 July 2008 } \\
\end{array}$ & $\begin{array}{l}\text { Kim, K.-Y. } \\
\text { Totti C. } \\
\text { Koike, K. } \\
\text { Koike, K. } \\
\text { Koike, K. } \\
\text { Takano, Y. } \\
\text { Takano, Y. } \\
\text { Takano, Y. } \\
\text { Nézan, E. } \\
\text { Nézan, E. }\end{array}$ & $\begin{array}{c}\text { EF613362 } \\
\text { Not sequenced } \\
\text { Not sequenced } \\
\text { Not sequenced } \\
\text { Not sequenced } \\
\text { Not sequenced } \\
\text { MG646299 } \\
\text { Not sequenced } \\
\text { Not sequenced } \\
\text { Not sequenced } \\
\end{array}$ & $\begin{array}{c}\text { Not } \\
\text { sequenced } \\
\text { AM183800 } \\
\text { MG646283 } \\
\text { MG646284 } \\
\text { MG646285 } \\
\text { MG646291 } \\
\text { MG646290 } \\
\text { MG646289 } \\
\text { Not } \\
\text { sequenced } \\
\text { Not } \\
\text { sequenced } \\
\end{array}$ & $\begin{array}{c}\text { AY421790 } \\
\text { AM183800*** } \\
\text { Not sequenced } \\
\text { Not sequenced } \\
\text { Not sequenced } \\
\text { MG646332 } \\
\text { MG646331 } \\
\text { Not sequenced } \\
\text { MG646317 } \\
\text { MG646318 } \\
\end{array}$ & $\begin{array}{c}\text { Kazuhiko Koike } \\
\text { Kazuhiko Koike } \\
\text { Kazuhiko Koike } \\
\text { Yoshihito Takano } \\
\text { Yoshihito Takano } \\
\text { Yoshihito Takano } \\
\text { Gwenael Bilien } \\
\text { Gwenael Bilien } \\
\end{array}$ \\
\hline 16-034 & Ceratocorys armata & Bouée 7, Arcachon, France & 44.54 & -1.26 & 18 Dec 2015 & Nézan, E. & MG646311 & $\begin{array}{c}\text { Not } \\
\text { sequenced }\end{array}$ & MG646329 & Gwenael Bilien \\
\hline $\begin{array}{l}16-246 \\
16-245 \\
\text { CCMP157 } \\
\end{array}$ & $\begin{array}{l}\text { Ceratocorys gourretii } \\
\text { Ceratocorys horrida } \\
\text { Ceratocorys horrida } \\
\end{array}$ & $\begin{array}{l}\text { Station B70, Banyuls-sur-mer, French } \\
\text { Mediterranean } \\
\text { Station B70, Banyuls-sur-mer, French } \\
\text { Mediterranean } \\
\text { Banda Sea, South East Asia }\end{array}$ & $\begin{array}{r}42.48 \\
-5,00 \\
\end{array}$ & $\begin{array}{c}3.18 \\
130,00 \\
\end{array}$ & $\begin{array}{r}26 \text { Sept } 2016 \\
22 \text { April } 1975 \\
\end{array}$ & $\begin{array}{l}\text { Nézan, E. } \\
\text { Sweeney, B. }\end{array}$ & $\begin{array}{c}\text { MG646310 } \\
\text { MG646312 } \\
\text { Not sequenced } \\
\end{array}$ & $\begin{array}{c}\text { Not } \\
\text { sequenced } \\
\text { Not } \\
\text { sequenced } \\
\text { EU927577 } \\
\end{array}$ & $\begin{array}{c}\text { MG646328 } \\
\text { MG646330 } \\
\text { AF022154 } \\
\end{array}$ & $\begin{array}{l}\text { Gwenael Bilien } \\
\text { Gwenael Bilien }\end{array}$ \\
\hline SCCAP K-1504 & Thecadinium kofoidii & Helgoland, Germany & 54.19 & 7.9 & Aug. 2002 & Hoppenrath, M. & GU295207**** & $\begin{array}{c}\text { Not } \\
\text { sequenced }\end{array}$ & GU295204 & \\
\hline JH0210 & Alexandrium affine & Jinhae Bay, South Korea & NA & $\mathrm{NA}$ & $\mathrm{NA}$ & $\mathrm{NA}$ & Not sequenced & $\begin{array}{c}\text { Not } \\
\text { sequenced }\end{array}$ & AY775286 & \\
\hline $\begin{array}{l}\text { JHW0004-12 } \\
\text { CCMP116 } \\
\end{array}$ & $\begin{array}{l}\text { Alexandrium tamarense } \\
\text { Alexandrium tamarense }\end{array}$ & $\begin{array}{l}\text { Korea } \\
\text { Ria de Vigo, Spain } \\
\end{array}$ & $\begin{array}{c}\mathrm{NA} \\
42.23 \\
\end{array}$ & $\begin{array}{l}\mathrm{NA} \\
-8.8 \\
\end{array}$ & $\begin{array}{c}\text { NA } \\
1 \text { June } 1984 \\
\end{array}$ & $\begin{array}{l}\text { NA } \\
\text { Yentsch, C.M. }\end{array}$ & $\begin{array}{c}\text { Not sequenced } \\
\text { HM483868 }\end{array}$ & $\begin{array}{c}\text { Not } \\
\text { sequenced } \\
\text { Not } \\
\text { sequenced } \\
\end{array}$ & $\begin{array}{c}\text { AY421777 } \\
\text { Not sequenced }\end{array}$ & \\
\hline $\begin{array}{l}\text { CCMP1738 } \\
\text { DRW0208 } \\
\text { BLACK1 } \\
\text { CASP1 } \\
\text { SANPEDRO1 } \\
\end{array}$ & $\begin{array}{l}\text { Lingulodinium polyedra } \\
\text { Lingulodinium polyedra } \\
\text { Lingulodinium polyedra } \\
\text { Lingulodinium polyedra } \\
\text { Lingulodinium polyedra } \\
\end{array}$ & $\begin{array}{l}\text { Gulf of Mexico, USA } \\
\text { Korea } \\
\text { Black Sea, Ukraine } \\
\text { Caspian Sea, Iran } \\
\text { San Pedro Harbor, California, USA } \\
\end{array}$ & $\begin{array}{c}27.8 \\
\mathrm{NA} \\
49.90 \\
37.51 \\
33.74 \\
\end{array}$ & $\begin{array}{c}-97.13 \\
\text { NA } \\
30.29 \\
49.91 \\
-118.24 \\
\end{array}$ & $\begin{array}{c}\text { NA } \\
\text { Aug. } 2001 \\
2011 \\
2011 \\
2011 \\
\end{array}$ & $\begin{array}{l}\text { Buskey, E. } \\
\text { NA } \\
\text { Takano, Y. } \\
\text { Takano, Y. } \\
\text { Takano, Y. }\end{array}$ & $\begin{array}{c}\text { Not sequenced } \\
\text { Not sequenced } \\
\text { AB678400 } \\
\text { AB678402 } \\
\text { AB678404 } \\
\end{array}$ & $\begin{array}{c}\text { Not } \\
\text { sequenced } \\
\text { Not } \\
\text { sequenced } \\
\text { AB678399*** } \\
\text { AB678401*** } \\
\text { AB678403*** } \\
\end{array}$ & $\begin{array}{c}\text { EF492507 } \\
\text { AY421788 } \\
\text { AB693195*** } \\
\text { AB693194*** } \\
\text { AB693196*** }\end{array}$ & \\
\hline GS0209 & Gonyaulax polygramma & Gunsan, South Korea & NA & $\mathrm{NA}$ & $\mathrm{NA}$ & $\mathrm{NA}$ & Not sequenced & $\begin{array}{c}\text { Not } \\
\text { sequenced } \\
\end{array}$ & AY775287 & \\
\hline $11 \mathrm{~A} 1$ & $\begin{array}{l}\text { Protoperidinium } \\
\text { tricingulatum }\end{array}$ & Wadden Sea, Netherlands & 53,60 & 6,58 & 2006 & Kawami, H. & Not sequenced & $\begin{array}{c}\text { Not } \\
\text { sequenced }\end{array}$ & AB716917 & \\
\hline CCAP1140/3 & Parvodinium inconspicuum & $\begin{array}{l}\text { Kl. Ukleisee, Schleswig-Holstein, } \\
\text { Germany }\end{array}$ & $\mathrm{NA}$ & $\mathrm{NA}$ & $\mathrm{NA}$ & Meyer & Not sequenced & $\begin{array}{c}\text { Not } \\
\text { sequenced }\end{array}$ & FR865631 & \\
\hline hwid1 & Unidentified & Hawaii & 21,59 & $-158,10$ & 04-mars-14 & $\begin{array}{l}\text { Anne de Vernal and } \\
\text { Geneviève Vautour }\end{array}$ & MG646298 & MG646295 & MG646320 & Haifeng Gu \\
\hline GgSm10R & Unidentified & Malaysia & 1,60 & 110,32 & 17-janv-13 & Bao Juan Kam & MG646305 & $\begin{array}{c}\text { Not } \\
\text { sequenced } \\
\text { Not }\end{array}$ & MG646326 & Haifeng Gu \\
\hline GgSm11R & Unidentified & Malaysia & 1,60 & 110,32 & 17-janv-13 & Bao Juan Kam & MG646306 & $\begin{array}{l}\text { sequenced } \\
\text { Not }\end{array}$ & MG646327 & Haifeng Gu \\
\hline GgSm01R & Unidentified & Malaysia & 1,60 & 110,32 & 10-août-10 & Toh Hii Tan & MG646302 & $\begin{array}{l}\text { sequenced } \\
\text { Not }\end{array}$ & MG646324 & Haifeng Gu \\
\hline GgSm03R & Unidentified & Malaysia & 1,60 & 110,32 & 22 -sept-10 & Toh Hii Tan & MG646303 & $\begin{array}{c}\text { sequenced } \\
\text { Not }\end{array}$ & Not sequenced & Guat Ru Liow \\
\hline GgSm07R & Unidentified & Malaysia & 1,60 & 110,32 & 17-janv-13 & Toh Hii Tan & MG646304 & $\begin{array}{l}\text { sequenced } \\
\text { Not }\end{array}$ & MG646325 & Zhen Fei Lim \\
\hline PrTT02R & Unidentified & Malaysia & 1,92 & 109,77 & 28-mars-13 & Sing Tung Teng & MG646308 & $\begin{array}{l}\text { sequenced } \\
\text { Not }\end{array}$ & Not sequenced & Haifeng Gu \\
\hline $\begin{array}{l}\text { PrTT03R } \\
\text { PrTT01R }\end{array}$ & $\begin{array}{l}\text { Unidentified } \\
\text { Unidentified }\end{array}$ & $\begin{array}{l}\text { Malaysia } \\
\text { Malaysia }\end{array}$ & $\begin{array}{l}1,92 \\
1,92\end{array}$ & $\begin{array}{l}109,77 \\
109,77\end{array}$ & $\begin{array}{l}28 \text {-mars-13 } \\
28-m a r-13\end{array}$ & $\begin{array}{l}\text { Sing Tung Teng } \\
\text { Sing Tung Teng }\end{array}$ & $\begin{array}{l}\text { MG646309 } \\
\text { MG646307 }\end{array}$ & sequenced & Not sequenced & $\begin{array}{l}\text { Haifeng Gu } \\
\text { Haifeng G }\end{array}$ \\
\hline
\end{tabular}


Ц 1 $*=$ single cells or cysts sequenced through single-cell PCR; Accession numbers in bold denote sequences from this study. ** = these cultures showed presence of 5 precingular plates and are considered aberrant. $* * * *$ sequence not used in
phylogenies. NA $=$ Not acknowledged. 